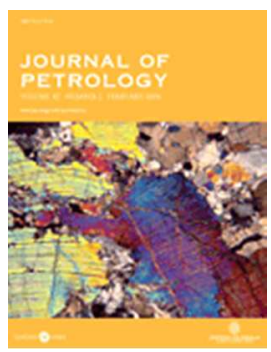

Draft Manuscript for Review

\title{
Compositional and thermodynamic variability in a stratified magma chamber: Evidence from the Green Tuff Ignimbrite (Pantelleria, Italy)
}

\begin{tabular}{|r|l|}
\hline Journal: & Journal of Petrology \\
\hline Manuscript ID & JPET-Mar-18-0028.R1 \\
\hline Manuscript Type: & Original Manuscript \\
\hline Date Submitted by the Author: & n/a \\
\hline Complete List of Authors: & $\begin{array}{l}\text { Liszewska, Katarzyna; University of Warsaw, IGMiP Faculty of Geology } \\
\text { White, John; Eastern Kentucky University, Geography \& Geology; } \\
\text { Macdonald, Raymond; Lancaster University, Environment Centre; } \\
\text { University of Warsaw, IGMiP Faculty of Geology } \\
\text { Bagiński, Bogusław; University of Warsaw, IGMiP Faculty of Geology }\end{array}$ \\
\hline Keyword: & Green Tuff ignimbrite, Pantelleria, zoned magma reservoir, magma mixing \\
\hline &
\end{tabular}

SCHOLARONE ${ }^{\text {M }}$

Manuscripts 
1

2

3

4

5

6

7

8

9

\section{Compositional and thermodynamic variability in a stratified magma 2 chamber: Evidence from the Green Tuff Ignimbrite (Pantelleria, Italy)}

3

4

5

6

7

8

9

\section{K.M. Liszewska ${ }^{1}$, J.C. White ${ }^{2}$, R. Macdonald ${ }^{1,3, *}$ and B. Bagiński ${ }^{1}$}

${ }^{1}$ IGMiP Faculty of Geology, University of Warsaw, al. Żwirki i Wigury 93, 02-089 Warsaw, Poland

${ }^{2}$ Department of Geociences, Eastern Kentucky University, Richmond, KY 40475, USA

${ }^{3}$ Environment Centre, Lancaster University, Lancaster LA1 4YQ, UK

*Corresponding author. e-mail; r.macdonald@lancaster.ac.uk. Telephone 0048227724953

\section{ABSTRACT}

The Green Tuff Ignimbrite, Pantelleria, is compositionally zoned from pantellerite at the base to comenditic trachyte at the top, the variation apparently representing an inverted vertical zonation in the pre-eruptive reservoir. The main phenocryst assemblages are alkali feldspar + olivine + clinopyroxene + ilmenite + apatite in the trachytes and alkali feldspar + aenigmatite + clinopyroxene \pm quartz in the rhyolites. Thermodynamic modelling indicates that the temperature range was $\sim 900-700^{\circ} \mathrm{C}, f \mathrm{O}_{2} \mathrm{FMQ}-1.5$ to FMQ- 0.5 and $a \mathrm{SiO}_{2}$ (relative to quartz saturation) $0.74-1.00$. Melt water contents ranged from $\sim 1 \mathrm{wt} \%$ in the trachytes to $\sim 4 \mathrm{wt} \%$ in the pantellerites. Matrix glass analyses in the more evolved rocks are highly variable, showing that compositional layers in the upper parts of the reservoir, formed by fractional crystallization, were mixed during eruption, the proportion of rhyolitic to trachytic melts increasing towards the top of the reservoir. Some areas of glass have low $\mathrm{Al}_{2} \mathrm{O}_{3}$ contents (5.16-5.46 wt \%) and high $\mathrm{FeO}^{*}$ contents (9.66-10.02 wt \%), making them the most evolved melts yet reported from Pantelleria. The new glass data stress how whole-rock analyses do not truly reflect the complete range of melt compositions in the pre-eruptive reservoir. The trachytes contain $>40 \%$ modal phenocrysts, which with relatively high Ba contents and positive Eu anomalies, are considered to have originated in a feldspar-accumulitic layer. Phenocrysts in the trachytes are commonly heavily resorbed, inferred to be a result of heating by influxes of intermediate composition magmas, which, however, were not erupted. It is argued that magma of intermediate composition were present in the Green Tuff reservoir but were efficiently trapped in a crystal-rich layer below the Green Tuff magmas, which was eventually erupted during a resurgent phase as the Montagna Grande Trachyte.

Key words: Green Tuff ignimbrite; Pantelleria; zoned magma reservoir; magma mixing 


\section{INTRODUCTION}

The island of Pantelleria, located in the Strait of Sicily continental rift system, is a composite, bimodal volcano, with alkali basalt and peralkaline rhyolite end-members. Rocks of intermediate composition, such as mugearites and benmoreites, are rare and in many, perhaps all, cases are products of magma mixing (Ferla \& Meli, 2006; Romengo et al., 2012). Despite intensive study since the 1960s, some aspects of the evolution of Pantelleria remain enigmatic, including (i) the location and nature of the magma reservoir(s), (ii) the genetic relationships between the mafic and silicic volcanic rocks, and (iii) the detailed changes in crystallization conditions during magma evolution. The deposit termed the Green Tuff is an important focus in addressing these, and related, problems.

(a) The Green Tuff is compositionally zoned from pantellerite to trachyte, which has been inferred to represent vertical compositional variation within the pre-eruptive magma chamber, with the pantellerites being erupted first. The zonation allows us to examine the genetic relationships between them in the products of one eruption, using whole-rock, matrix glass and mineral chemical data.

(b) The trachytic members show strong textural disequilibrium, which must be related to processes in the lower part of the erupted magma reservoir, such as thermal and/or compositional inputs from more mafic melts via magma mixing. This, in turn, can provide evidence on the material in the sub-trachyte part of the chamber and thus on the existence or otherwise of a composition (Daly) gap in the plumbing system.

(c) The phenocryst assemblages are suitable for estimating such parameters as temperature, $f \mathrm{O}_{2}$ and $a \mathrm{SiO}_{2}$, how they varied with melt composition and inferred depth in the magma chamber prior to eruption and the evidence they provide for a volatile gradient. 


\section{GEOLOGICAL SETTING}

55

56

57

Pantelleria is located in the NW-SE trending Strait of Sicily Rift Zone (Fig. 1). The rift cuts the Pelagian Block, a promontory of the African plate. The crustal thickness under most of the Block is $25-35 \mathrm{~km}$, thinning to $16-17 \mathrm{~km}$ in the rift zone (Civile et al., 2008). The Pantelleria Trough is one of three basins within the rift; it is a deep trough with a bathymetric low reaching a depth of $-1317 \mathrm{~m}$ (Morelli et al., 1975). The trough has a strong positive Bouguer anomaly (65-103 mgal; Behncke et al. 2006; Civile et al., 2008). It also has a high average heat flow (94 $\pm 21 \mathrm{~mW} / \mathrm{m}^{2}$; Verzhbitsky \& Kononov, 2003), which contrasts with the continental average of $55 \mathrm{~mW} / \mathrm{m}^{2}$ but is in line with the fact that southern Italy is a hot spot in Europe, with an average of $70 \mathrm{~mW} / \mathrm{m}^{2}$ (Chapman \& Pollack, 1975). These features have been taken to indicate the presence of abundant basaltic magmas at depth (Della Vedova et al., 1995 ) and asthenospheric upwelling to $\sim 60 \mathrm{~km}$, which is coincident with the maximum depth of earthquake foci that have been recorded in this area (Calò and Parisi, 2014). Little is known of the composition of the submerged part of Pantelleria. Geophysical work by Gantar et al. (1961) showed that it comprises a large volume of high density rocks $\left(3000 \mathrm{~kg} / \mathrm{m}^{3}\right)$. By analogy with Linosa, a volcanic island some $100 \mathrm{~km}$ SE of Pantelleria in the Strait of Sicily, the rocks may be dominated by basalts and hawaiites (Villari, 1974). The most recent, basaltic, eruption in the area was submarine and occurred a few kilometres to the NW of the island in 1891.

At the current level of exposure, Pantelleria is dominated ( 94\%; Mahood \& Stimac, 1986) by trachytes and rhyolites. Eruption of basalts and hawaiites has been restricted to the northern part of the island. Furthermore, a well (PPT2) drilled in the northern section penetrated, at $180 \mathrm{~m}$ depth, more than $600 \mathrm{~m}$ of basaltic lavas and hyaloclastites cut by 3 
dolerite dykes (Fulignati et al., 1997). A basaltic component has been recognized in mixed magma rocks from various centres on the island, indicating the continuing presence of mafic magma at depth (Ferla \& Meli, 2006; Romengo et al., 2012). Magmatic activity at Pantelleria is undoubtedly basalt-driven, in that basaltic magma is the fundamental source of mass, heat and volatiles in the system.

The Green Tuff forms a thin cover over much of the $83 \mathrm{~km}^{2}$ island, draping all topographic landforms (Fig. 1). High-precision ${ }^{40} \mathrm{Ar} /{ }^{39} \mathrm{Ar}$ dating has given an eruption age of $45.7 \pm 1.0 \mathrm{ka}$ (2б) (Scaillet et al., 2013). The volume (in DRE: dense rock equivalent) has been variously estimated as $0.28 \mathrm{~km}^{3}$ (Jordan et al., 2018), $1.5 \mathrm{~km}^{3}$ (Civetta et al., 1988), $3.5 \mathrm{~km}^{3}$ (Mahood \& Hildreth, 1986) and $7 \mathrm{~km}^{3}$ (Wolff \& Wright, 1981). The range partly reflects uncertainty in the amount of material that fell into the sea: distal ash from the eruption has been identified as far away as the Dodecanese, $1300 \mathrm{~km}$ east of Pantelleria (Margari et al., 2007). Taking into account the offshore deposit, Margari et al. (2007) suggested a bulk ash volume of $\sim 10 \mathrm{~km}^{3}$ DRE. The range also reflects the very variable thickness of the Green Tuff, from $30 \mathrm{~cm}$ to $>10 \mathrm{~m}$ in palaeovalleys (Orsi \& Sheridan, 1984). The deposit has been variously interpreted as a welded ignimbrite (Villari, 1974), a welded fall deposit (Wolff \& Wright, 1981) and a sequence of pyroclastic flow units including welded fall and surge members (Orsi \& Sheridan, 1984). Mahood \& Hildreth (1986) described the Green Tuff as a Plinian deposit, commencing with fallout beds followed by pyroclastic flows. In the fullest, most recent study Williams et al. (2014) interpreted the Green Tuff as a Plinian fall deposit overlain by a single ignimbrite flow unit.

The location and nature of the eruptive sources of the Green Tuff are debatable. Following Mahood \& Hildreth (1986), it has generally been accepted that eruption of the Green Tuff at $45.7 \pm 1.0 \mathrm{ka}$ was related to the formation of the Cinque Denti caldera $\left(\sim 30 \mathrm{~km}^{2}\right)$, the younger 
101 of the two calderas on the island (Fig. 1). Wright (1980) argued for a central vent on the

102 western side of the Cinque Denti caldera, whereas Mahood \& Hildreth (1986) located the vent

103 at the southern end of the caldera or in the Monte Gibele area. Williams et al. (2014)

104 suggested that the vent was on the northwestern slope of Montagna Grande. In contrast,

105 Catalano et al. (2014) proposed that the tuff was erupted from fissures superimposed on NNE-

106 trending normal fault zones within the caldera complex. They further proposed that the

107 eruption caused only a partial collapse of the southeastern walls of the caldera, the main part

108 of which had formed earlier, perhaps at $\sim 87 \mathrm{ka}$. Most recently, Jordan et al. (2018) have

109 argued that there have been five, or more, periods of caldera collapse on Pantelleria and that

110 the eruption of the Green Tuff was accompanied by only partial collapse along previously

111 established faults.

112 The Green Tuff is continuously zoned from comenditic trachyte at the top to pantellerite at 113 the bottom, reflecting in reverse order the eruption from a zoned magma chamber (Mahood, 114 1984; Civetta et al., 1988; Mahood \& Hildreth, 1986; Williams et al., 2014). Judging from the 115 stratigraphic height versus composition profile in Williams et al (2014), the trachyte forms an 116 estimated 5-10\% of the deposit. An important aspect of the Green Tuff, in terms of the 117 evolution of Pantelleria, is that its eruption marked a peak in melt production and in the 118 peralkalinity of the magmas, after a long inter-eruptive period following the 85 ka eruptive 119 episode (Mahood \& Hildreth, 1986; Scaillet et al., 2013). On the basis of new ${ }^{40} \mathrm{Ar} /{ }^{39} \mathrm{Ar}$ 120 dating and geodetic evidence of deflation and subsidence of the caldera floor, Scaillet et al. 121 (2011) proposed that the intracaldera system, in stasis since $7 \mathrm{ka}$, is on the wane and that there 122 is no evidence of a forthcoming eruption.

123 Formation of the Green Tuff was followed by eruption onto the caldera floor of the 124 volcanic rocks forming Monte Gibele (44-37 ka), which was subsequently uplifted as a 
125 resurgent block and then tilted to form Montagna Grande at $\sim 18$ ka (Fig. 1) (Mahood \&

126 Hildreth, 1986; Orsi et al., 1991; Lanzo et al., 2013). This edifice is composed dominantly of

127 metaluminous trachytes, with a single recorded example of benmoreite lava (Romengo et al.,

128 2012). K-Ar dates for the trachytes overlap those of the Green Tuff, prompting Mahood \&

129 Hildreth (1986) to suggest that the trachytic activity was a continuation of the Green Tuff

130 activity, i.e. it was probably part of the same magmatic system, where continuing eruptions

131 were a response to isostatic compensation for the material ejected during caldera formation. In

132 contrast, Civetta et al. (1988) considered the Green Tuff activity to be a late-stage part of the

133 earliest of six eruptive cycles on Pantelleria, whereas Montagna Grande was the earliest part

134 of a second cycle. However, the existence of the six cycles has been questioned by Scaillet et

135 al. (2011), partly on the basis of newer, high precision ${ }^{40} \mathrm{Ar} /{ }^{39} \mathrm{Ar}$ ages. In the activity of the

136 past $20 \mathrm{ka}$, they recognized a long-term ( $>15 \mathrm{ka})$ decline in eruptive frequency associated with

137 a prominent palaeosol horizon marking a volcanic hiatus between 12 and $14 \mathrm{ka}$.

138 Using the joint inversion of geodetic data (levelling, EDM and InSAR), Mattia et al. (2007)

139 found that the main caldera is subsiding and proposed that the measured ground deformation

140 pattern can be explained by a simple spherical source located at $\sim 4 \mathrm{~km}$ beneath the caldera.

141 The subsidence was related to the cooling of a hydrothermal system beneath the caldera.

142 Lanzo et al. (2013) combined $\mathrm{Cl}$ and $\mathrm{H}_{2} \mathrm{O}$ solubility data to estimate a confining pressure of

143 about $50 \mathrm{MPa}$ (depth $\sim 2-3 \mathrm{~km}$ ) for the Green Tuff magma chamber, the shallow depths being

144 consistent with petrological estimates for other pantellerite eruptions on the island

145 (Lowenstern, 1994; White et al., 2005, 2009; Di Carlo et al., 2010; Neave et al., 2012).

147 Lithostratigraphy of the Green Tuff 
148 The Green Tuff is a very complex eruptive unit, showing major lateral and vertical

149 heterogeneity. Primary depositional features have been obscured by various combinations of

150 dense welding, strong rheomorphism and revesiculation. Standard methods of correlation

151 along strike, such as the use of lithofacies, have proved inadequate. For example, Lanzo et al.

152 (2013) divided the tuff into five members on the basis of the clearly visible variations of some

153 megascopic features, including welding, crystal content and rheomorphic structures. Catalano

154 et al. (2014) grouped the many lithofacies in the tuff into three major lithostratigraphic

155 intervals, which show many differences in detail to the Lanzo et al. (2013) scheme.

156 In an innovative approach, Williams et al. (2014) used compositional variation within the

157 deposit, as exemplified by $\mathrm{Zr}$ abundance, as a measure of stratigraphic height. They

158 established a type section on the Monastero scarp (Fig. 1) which shows a continuous decrease

159 of whole-rock Zr contents from $\sim 2000$ to $300 \mathrm{ppm}$ with height within the section (Fig. 2).

160 Lateral correlations were then made on the basis of $\mathrm{Zr}$ content being a time-marker during

161 eruption of the tuff. It will be shown below that magma mixing was a significant process

162 during eruption of the tuff, such that individual whole-rock analyses may reflect the range and

163 proportions of mixed components. In this report, it is assumed that the highest level in the

164 reservoir being tapped by the eruption of any given magma batch is given by the highest $\mathrm{Zr}$

165 glass content in that sample. The inferred positions of samples are consistent with the field

166 occurrence, where known, e.g. the basal pumice fall, basal vitrophyre and upper vitrophyre

167 (Fig. 2).

168

169

SAMPLING AND ANALYTICAL METHODS

7

http://www.petrology.oupjournals.org/ 
170 The aims of this study included determining the range of melt compositions in the Green Tuff,

171 and studying in detail the melt-phenocryst relationships. It was critical, therefore, that,

172 wherever possible, pristine melt (glass) compositions were determined. The only previous

173 study to focus on glass compositions in the Green Tuff is that of Williams et al. (2014).

174 However, as they acknowledge, the beam diameter used in their laser ablation inductively

175 coupled mass spectrometry (LA-ICP-MS) determinations was sufficiently large that their

176 analyses probably included glass and microlites. The electron microprobe technique used here

177 allowed us to focus on areas of clean glass, although the presence of submicroscopic

178 microlites cannot be excluded in every case. Samples were collected from 15 localities

179 (Appendix). Glass was found in 11 samples; certain facies of the tuff, especially strongly

180 welded and trachytic varieties, are completely devitrified. A small number of analyses of glass

181 inclusions in phenocrysts have also been made.

182 Two whole-rock analyses (samples 090531 and 090533) were made at Activation

183 Laboratories, Ancaster, Ontario, for major elements and $\mathrm{Cu}, \mathrm{Ni}, \mathrm{Pb}$ and $\mathrm{Zn}$ by ICP-AES

184 (Code 481) and other trace elements by ICP-MS (Code 4Lithoresearch), F by ion selective

185 electrode (Code 4F-F) and $\mathrm{Cl}$ by INAA (Code 4F-Cl). The remaining fifteen whole-rock

186 analyses were made at Bureau Veritas Commodities Canada Ltd (Table 2). Major elements

187 and Cr were analysed by ICP-ES, and trace elements, including REE, by ICP-MS. Mean

188 detection limits on major elements was close to $0.1 \mathrm{wt} \%$ whilst the detection limits for trace

189 elements varied from 0.01 to $0.1 \mathrm{ppm}$.

190 Mineral compositions were determined by electron microprobe at the Inter-Institute

191 Analytical Complex at the Institute of Geochemistry, Mineralogy and Petrology, University of

192 Warsaw, using a Cameca SX-100 microprobe equipped with four wavelength dispersive

193 spectrometers. The analytical conditions for minerals, except feldspar, were: accelerating 
194 voltage $15 \mathrm{kV}$ and probe current $20-40 \mathrm{nA}$, with counting times of $20 \mathrm{~s}$ on peak and $10 \mathrm{~s}$ on

195 each of two background positions. For feldspar, a beam spot diameter of $5 \mu \mathrm{m}$ was used, to

196 reduce Na loss. For glass analyses, $15 \mathrm{kv}$ and 6-10 nA and a dispersed spot of $\sim 10-20 \mu \mathrm{m}$

197 were used. Certain problems can arise with analysis of glass. As well as compositional

198 variations related to incomplete mixing of melts, melts may have been heterogeneous because

199 of (i) proximity to different phenocrysts and (ii) contamination by microlites. In our

200 experience, for example, contamination by feldspar and FeTi-oxide microlites can cause some

201 scatter in $\mathrm{Fe}$ and $\mathrm{Al}$ abundances. We have attempted to mitigate these problems by analyzing

202 clear pools of matrix glass as far as possible from phenocryst phases.

203 The 'PAP' $\varphi(\rho Z)$ program (Pouchou \& Pichoir, 1991) was used for corrections. Apatite was 204 analysed using the technique outlined in Macdonald et al. (2008). Estimates of analytical 205 precision $(1 \sigma ; \mathrm{wt} \%)$ for all phases except glass are: Si 0.07, Ti 0.03, Al 0.02, Cr 0.02, Ni $206 \quad 0.03, \mathrm{Fe} 0.09, \mathrm{Mn} 0.03, \mathrm{Mg} 0.04, \mathrm{Ca} 0.08, \mathrm{Na} 0.01, \mathrm{~K} 0.01$. For glass analyses, the values are 207 Si 0.40, Ti 0.03, Al 0.14, Fe 0.29, Mn 0.12, Mg 0.02, Ca 0.03, Na 0.17, K 0.11, P 0.03, Zr $2080.08, \mathrm{Cl} 0.03, \mathrm{~F} 0.08$. The numbers of point analyses presented are: phenocrysts: alkali 209 feldspar 501; fayalite 102; hedenbergite 171; FeTi-oxides 27; aenigmatite 58; apatite 10:

210 matrix glass and melt inclusions 145 . Representative glass analyses are given in Table 3; the

211 full phenocryst and glass data set is given in Electronic Appendices 1-3 (available at

212 http://www.petrology.oxfordjournals.org). 
216 Phenocryst assemblages are presented in Table 1. Alkali feldspar phenocrysts are present in

217 all samples, its abundance ranging from $30-40$ modal $\%$ in the comenditic trachytes to $<10$

218 modal\% in the pantellerites. Mafic phenocrysts are much less abundant, normally occurring in

219 total in amounts less than 5 modal\%. Exceptions are clinopyroxene in sample $150521(\sim 5 \%)$

220 and aenigmatite in $150514(\sim 2-3 \%)$.

221 Whereas the alkali feldspar phenocrysts in the rhyolites tend to be euhedral to subhedral,

222 homogeneous and up to $3 \mathrm{~cm}$ across, those in the trachytes are commonly highly resorbed

223 (c.f. Korringa \& Noble, 1972; Troll \& Schmincke, 2002; Romengo et al., 2012; D’Oriano et

$224 a l ., 2017$ ) (Fig. 3 (a), (b). Resorbed and euhedral crystals are sometimes present together in

225 mixed magma rocks. Olivine phenocrysts occur in the less peralkaline rocks, commonly

226 showing highly resorbed textures (Fig. 3(c)). Clinopyroxene is ubiquitous, varying in form

227 from perfectly euhedral to partially resorbed plates (Fig. 3(d)). Zoning is common, marked by

228 differing shades of green.

229 Quartz phenocrysts are rounded and up to $1 \mathrm{~cm}$ in size. They are found only in the more

230 peralkaline host glasses and appear to have been of relatively late crystallization, consistent

231 with the observation of Di Carlo et al. (2010) from their experimental work on Pantescan

232 pantellerites. Aenigmatite phenocrysts, most commonly forming euhedral prisms, are also

233 restricted to the more peralkaline hosts. Ilmenite occurs throughout the whole-rock

234 compositional range, commonly in association with clinopyroxene and olivine but also as

235 discrete subhedral crystals. Titanomagnetite is scarcer, more texturally variable: it is present

236 as equant microphenocrysts, forms rims to ilmenite phenocrysts and occurs as tiny crystals

237 along the rims of melt inclusions. No exsolution lamellae have been seen. Apatite

238 microphenocrysts occur over the complete whole-rock compositional range, although they are

239 most abundant in the trachytic members. They most commonly form euhedral prismatic 
240 crystals, up to a few tens of $\mu \mathrm{m}$ long, associated with clinopyroxene and olivine phenocrysts.

241 Pyrrhotite occurs in most samples, usually as small crystals $(<20 \mu \mathrm{m})$ enclosed in olivine and 242 clinopyroxene phenocrysts.

243 As noted above, many samples contain glass of more than one composition and the

244 phenocryst assemblages reflect those compositional ranges. Taking this into account, some

245 general observations of phenocryst distribution can be made. The two dominant assemblages

246 are (i) alkali feldspar + fayalite + hedenbergite + ilmenite + apatite, and (ii) alkali feldspar +

247 hedenbergite + aenigmatite \pm ilmenite \pm quartz + apatite. Assemblage (ii) occurs in the more

248 peralkaline rocks and (i) in the more trachytic types. Samples containing phases more

249 commonly found in melts of slightly different composition, e.g. fayalite and aenigmatite in

250 samples 150534 and 150551 (Table 1), contain glass of more than one composition and the

251 phenocryst assemblages may reflect those compositional ranges. However, it will be shown

252 below that the assemblage fayalite + ilmenite + aenigmatite may be in equilibrium under very 253 specific conditions.

254

\section{Glass}

\section{6}

The majority of samples contain two or more varieties of glass, the relationships between them being very variable. In some cases, the glasses have different colours in plane polarised light, reflecting differing degrees of devitrification or microvesicularity without significant compositional differences. In others, the colours reflect magma mixing, which takes several forms. In Fig. 4(a), rounded blobs of black glass are mingled with a pale brown type. Both types contain alkali feldspar phenocrysts. Figure 4 (b) shows streaky intermingling of dark brown and pale glasses, feldspar phenocrysts being more common in the dark variety. Slightly 
263 denser welding in Fig. 4 (c) has resulted in mingling of narrow fiamme, the paler type being

264 more devitrified. The less densely welded sample in Fig. 4 (d) shows pale and slightly deeper

265 brown glasses patchily intermingled along their junction. No relationship between the type of

266 mixing and height within the deposit has been discerned.

267 Apart from two point analyses in clinopyroxene, all analyses of melt inclusions were made 268 in alkali feldspar phenocrysts (Electronic Appendix 3). The inclusions are similar to those 269 described from the Green Tuff by Lanzo et al. (2013); the dominant forms are ovoidal and 270 subspherical, up to $250 \mu \mathrm{m}$ across. The analysed inclusions are composed entirely of glass.

\section{PHENOCRYST COMPOSITIONS}

273 Alkali feldspar phenocrysts are anorthoclase in the compositional range $\mathrm{An}_{10} \mathrm{Ab}_{70} \mathrm{Or}_{20}$ to $274 \mathrm{An}_{0} \mathrm{Ab}_{63} \mathrm{Or}_{37}$, with an outlier at $\mathrm{Or}_{40}$ (Electronic Appendix 1(a)). The Or and Fe contents 275 generally increase with whole-rock peralkalinity. Barium levels $(\leq 0.01 \mathrm{apfu})$ are detectable 276 only in feldspars with $\mathrm{CaO}>0.5 \mathrm{wt} \%$. The compositional range within samples is usually 277 small; e.g. in 150511,150546 and 150551 the range is Or $<3$. In others, e.g. 150541, a slightly 278 larger range $\left(\mathrm{An}_{6.2} \mathrm{Ab}_{73.5} \mathrm{Or}_{20.3}\right.$ to $\left.\mathrm{An}_{0.2} \mathrm{Ab}_{68.2} \mathrm{Or}_{31.8}\right)$ reflects phenocryst occurrence in glasses 279 of different composition. With the exception of those with higher $\mathrm{CaO}$ contents $(>0.6 \mathrm{wt} \%)$, 280 all the alkali feldspar phenocrysts have peralkalinity indices (P.I. = molar $281\left(\left(\mathrm{Na}_{2} \mathrm{O}+\mathrm{K}_{2} \mathrm{O}\right) / \mathrm{Al}_{2} \mathrm{O}_{3}\right)$ in the range 1.0 to 1.14 .

282 Olivine phenocryst compositions are in the range $\mathrm{Fo}_{6-25}$, the Fo content decreasing with 283 increasing whole-rock peralkalinity (Electronic Appendix 1 (b)). They show high abundances 284 of $\mathrm{MnO}(3.7-4.6 \mathrm{wt} \%)$. Calcium levels are moderate, $\leq 0.75 \mathrm{wt} \% \mathrm{CaO}$, and show a positive 285 correlation with Fo, except for sample 150541 where the olivines are relatively Ca-poor. 
Zoning is generally small, $<1 \%$ Fo, except for one strongly resorbed crystal in 150513 where the range is $\mathrm{F}_{9.8-6.3 .}$. The clinopyroxene phenocrysts are sodian hedenbergite, ranging from $\mathrm{Ca}_{44} \mathrm{Mg}_{29} \mathrm{Fe}_{28}$ to $\mathrm{Ca}_{37} \mathrm{Mg}_{9.0} \mathrm{Fe}_{54}$ and with Mg-number from 51.0 to 12.5 (calculated with $\mathrm{Fe}$ as $\mathrm{Fe}^{2+}$ ) (Electronic Appendix 1(c)). Mg-numbers decrease with increasing host-rock peralkalinity. Oxidation ratios $\left(\mathrm{Fe}^{3+} /\left(\mathrm{Fe}^{3+}+\mathrm{Fe}^{2+}\right)\right)$, calculated from stoichiometry, range from 0.01 to 0.22 and are negatively correlated with $\mathrm{Mg}$-number. Sodium levels are also negatively correlated with Mg-number, varying from 0.05 to 0.20 apfu. All are peralkaline, in the sense of having $\mathrm{Na} / \mathrm{Al}>1$. Zonation within crystals is usually limited $\left(\leq \mathrm{En}_{4}\right)$ but in one crystal in 150541 En ranges from 12.8-21.7\%. Clinopyroxene-melt exchange coefficients $\mathrm{Kd}^{\mathrm{Fe}-\mathrm{Mg}}$ (calculated with all $\mathrm{Fe}$ as $\mathrm{Fe}^{2+}$ ) range from 0.11-0.13. This is comparable to values (0.14-0.16) found experimentally in a Pantescan pantellerite by Di Carlo et al. (2010) and in Kenyan comendites by Scaillet $\&$ Macdonald (2003).

With increasing host-glass peralkalinity, the aenigmatite phenocrysts in the Green Tuff contain more Na and less $\mathrm{Ca}$ and Al (c.f. Mahood \& Stimac, 1990) (Electronic Appendix 2 (a)). The compositional variation can generally be expressed by the coupled substitution $\mathrm{Si}^{4+}$ $+\mathrm{Na}^{+} \leftrightarrow \mathrm{Al}^{3+}+\mathrm{Ca}^{2+}$ (Kunzmann, 1999) (Fig. 5). The new analyses extend slightly the compositional range on Pantelleria. Ilmenite phenocrysts are in the narrow range $X_{\mathrm{ilm}} 0.95$ 0.99, with $\mathrm{Nb}_{2} \mathrm{O}_{5}$ levels $\leq 0.60 \mathrm{wt} \%$ and $\mathrm{MnO} 1.96-3.19 \mathrm{wt} \%$ (Electronic Appendix 2 (b)). Limited data are available for magnetite (Electronic Appendix 2(b)). The phase rimming an ilmenite phenocryst in 150513 has the composition $X_{\text {usp }} 0.47-0.49$, the core of a microphenocryst in 150541 is $X_{\text {usp }} 0.62$ and an inclusion in olivine is $X_{\text {usp }} 0.72-0.76$.

Mahood \& Stimac (1990) presented analyses of fluorapatite in three Green Tuff rocks spanning the compositional range trachyte to pantellerite. They noted that the REE and Si contents and the $\mathrm{La} / \mathrm{Ce}$ and $\mathrm{La} / \mathrm{Y}$ ratios increased, and $\mathrm{Ca}$ and $\mathrm{P}$ contents decreased, with 
310 increasing host-rock peralkalinity. Our new data (Electronic Appendix 2 (c)) largely confirm

311 their observations, although slightly increasing the britholite component, as measured by

312 REE + Y + Si contents, up to nearly $5 \%$.

\section{GEOCHEMISTRY}

\section{Whole-rock compositions}

316 Compositional modification of peralkaline silicic rocks through secondary hydration and/or partial

317 devitrification is well established (e.g. Noble, 1967, 1970; Noble et al., 1967; Baker \& Henage, 1977;

318 Weaver et al., 1990). Particularly important is the potential loss of $\mathrm{Na}$ which affects the calculation of

319 the P.I. As an alternative measure of peralkalinity, White et al. (2003) introduced the index FK/A

320 (mol. $(\mathrm{Fe}+\mathrm{K}) / \mathrm{Al}$, with all $\mathrm{Fe}$ calculated as $\mathrm{Fe}^{2+}$ ), on the basis that $\mathrm{Fe}, \mathrm{K}$ and $\mathrm{Al}$ are considerably less

321 mobile in aqueous systems than $\mathrm{Na}$ and because of the strong positive correlation between P.I. and

322 FK/Al in non-hydrated peralkaline rocks. Plots of FK/Al against P.I. for Green Tuff rocks and glasses

323 show a good positive correlation (Fig. 6). However, some point analyses appear to have $\mathrm{Na}_{2} \mathrm{O}$ values

324 rather lower than those predicted from the FK/Al values. Loss of $\mathrm{Na}$ cannot, therefore, be precluded

325 from all our samples, especially those with high LOI values, e.g. 150542 in Table 2, where secondary

326 hydration was the alteration process. Evidence for the loss of $\mathrm{Na}$ in a vapour phase is the presence in

327160541 of the rare mineral tuhualite $\left(\mathrm{NaFe}^{3+} \mathrm{Fe}^{2+} \mathrm{Si}_{6} \mathrm{O}_{15}\right)$, which Bagiński et al. (2018) showed was

328 precipitated in vesicles during and after devitrification of the tuff. Furthermore we cannot preclude

329 some loss of $\mathrm{Na}$ under the electron beam, which would be more marked in hydrated glasses.

330 Classification of the whole-rocks has been made using the scheme for peralkaline silicic rocks of

331 Macdonald (1974). In the scheme, the data form a continuous trend from comenditic trachyte to

332 pantellerite (Fig. 7). Whole-rock compositions are plotted against $\mathrm{SiO}_{2}$ in Fig. 8. With increasing 
$\mathrm{SiO}_{2}, \mathrm{Al}_{2} \mathrm{O}_{3}, \mathrm{TiO}_{2}, \mathrm{MgO}, \mathrm{CaO}$ contents decrease and $\mathrm{Na}_{2} \mathrm{O}$ and $\mathrm{F}$ contents increase; $\mathrm{K}_{2} \mathrm{O}$ peaks at $\mathrm{SiO}_{2} \sim 69$ wt \% (Fig. 8 (a)). Total Fe decreases to $\mathrm{SiO}_{2} \sim 66$ wt \% and then increases.
\end{abstract}

Barium, $\mathrm{Sr}$ (and $\mathrm{Ni}, \mathrm{Sc}$ and $\mathrm{V}$ ) contents are negatively correlated with $\mathrm{SiO}_{2}$, i.e. are enriched in the trachytic members (Fig. 8 (b)). The incompatible trace elements (ITE; Be, Cs, Hf, $\mathrm{Nb}$, $\mathrm{Rb}$; Ta, Th, $\mathrm{U}$ and $\mathrm{Zr}$ ) generally show positive correlations with $\mathrm{SiO}_{2}$ and P.I. Gallium shows an initial increase and then the trend flattens. An important observation is that data from the Montagna Grande Trachyte overlap with those of the Green Tuff, consistent with a genetic relationship between them (Mahood \& Hildreth, 1986).

Chondrite-normalised REE patterns for Green Tuff whole-rocks are shown in Fig. 9 (a). The patterns are LREE-enriched; more trachytic types show gently decreasing values from Gd to $\mathrm{Lu}$, whereas the most peralkaline types have flat patterns between Gd and Lu. Europium anomalies $\left(\mathrm{Eu} / \mathrm{Eu}^{*}\right)$ range from 1.08 in comenditic trachyte 150522 to 0.41 in pantellerite 160541.

\section{Glass compositions}

Representative matrix glass compositions are given in Table 3 and the full data set in Electronic Appendix 3. The spread in $\mathrm{SiO}_{2}$ values is from 62.8 to $73.7 \mathrm{wt} \%$ and the glasses range from comenditic trachyte to pantellerite (Fig. 7). Melt inclusions in phenocrysts cover a similar compositional range (Electronic Appendix 3) and will be discussed in conjunction with the matrix glass.

As noted earlier, alkali migration on devitrification and secondary hydration has affected the melt P.I. but it appears that the glasses, including the trachytic varieties, were all peralkaline. The compositional variations are generally similar to those in the whole-rocks, although the range extends to both more silica-rich and less silica-rich types (Fig. 8 (a)). It 15 
may also be noted that the highest Zr abundance (3183 ppm in sample 150544; Electronic Appendix 3) is distinctly higher than the maximum recorded in previous studies of Pantescan rocks and glass (2300 ppm; Williams et al., 2014).

On the $\mathrm{FeO}^{*}-\mathrm{Al}_{2} \mathrm{O}_{3}$ plot (Fig. 7), the glasses show significantly more complexity than the whole-rocks. The sub-horizontal trend across the comenditic trachyte field (Trend 1) shown by samples 150522 and 150534 may be the result of alkali feldspar being the sole liquidus phase in these melts, which results in an increase in $\mathrm{FeO}^{*}$. The change in slope at $\sim 6 \mathrm{wt} \%$ $\mathrm{FeO}^{*}$ (Trend 2) could mark the onset of clinopyroxene fractionation, after which the glass analyses follow a trend similar to the whole-rock analyses. At $\sim 9 \mathrm{wt} \% \mathrm{FeO}^{*}$, two subtrends emerge. Most glass analyses decrease sharply to $\sim 7 \mathrm{wt} \% \mathrm{FeO}^{*}$ at near-constant $(\sim 7-8 \mathrm{wt} \%)$ $\mathrm{Al}_{2} \mathrm{O}_{3}$ (Trend 3B). The glasses and melt inclusions at $\sim 9 \mathrm{wt} \% \mathrm{FeO} *$ have a normative composition very similar to the experimentally determined minimum of Carmichael \& MacKenzie (1963); we posit that this trend reflects crystallization of aenigmatite along the quartz-feldspar cotectic, which would allow $\mathrm{Zr}$, which is incompatible in all phases (Mahood \& Stimac, 1990; Neave et al., 2012) to continue to increase as FeO* decreases and P.I. remains relatively constant $(1.83 \pm 0.18$ for $\mathrm{Zr}>1500 \mathrm{ppm})$.

The other trend (Trend 3A) consists solely of glass and melt inclusions in sample 150514, which continue the whole-rock trend to $\sim 10 \mathrm{wt} \% \mathrm{FeO} *$ and $5.3 \mathrm{wt} \% \mathrm{Al}_{2} \mathrm{O}_{3}$ (corresponding to P.I. $=2.61$ and $2961 \mathrm{ppm} \mathrm{Zr})($ Table 3 and Electronic Appendix 3). These unusually low $\mathrm{Al}_{2} \mathrm{O}_{3}$ contents, high $\mathrm{FeO}^{*}$ contents and high P.I. make them the most evolved melts yet recorded from Pantelleria (Fig. 7). They are, however, broadly similar to glasses (FeO* 14-15 $\mathrm{wt} \%$ and $\mathrm{Al}_{2} \mathrm{O}_{3}$ 5-6 wt $\%$ ) formed in the experiments of Di Carlo et al. (2010) and they approach the effective minimum composition for peralkaline silicic magmas $\left(\mathrm{FeO}^{*} \sim 13 \mathrm{wt} \%\right.$, $\mathrm{Al}_{2} \mathrm{O}_{3} \sim 5 \mathrm{wt} \%$ ) proposed by Macdonald et al. (2012). It is possible that pockets of highly 16 
380 differentiated melt were locally developed in the Green Tuff reservoir, perhaps promoted by

381 unusually high F contents of the magma, as recorded in the glass in $150514(\leq 0.9 \mathrm{wt} \%$

382 (Electronic Appendix 3). The high F contents could have lowered melt viscosity and allowed 383 crystal fractionation to continue to slightly lower temperatures.

384 No new REE data for glass are presented here. However, chondrite-normalized REE 385 patterns for data in Mahood \& Stimac (1990), Neave et al. (2012) and Williams et al. (2014).

386 are broadly similar to those in the whole-rocks (Fig. 9 (b)). An unusual feature of several 387 trachytic glass and melt inclusion analyses reported in the literature is positive Eu anomalies $388\left(\mathrm{Eu} / \mathrm{Eu}^{*}=1.12-1.36\right)$, accompanied by Ba concentrations up to $1308 \mathrm{ppm}$ (Mahood \& 389 Stimac, 1990; Williams et al., 2014; Romano et al., 2018). Positive Eu anomalies are 390 characteristic of Pantescan basalts that may be parental to these trachytes (Civetta et al., 1998; 391 White et al., 2009). Coupled with low plagioclase/melt partition coefficients for Eu in the 392 basalts (0.13; Neave et al., 2012), it is possible that this is an inherited feature preserved 393 through fractional crystallization (Romano et al., 2018). However, crystal accumulation and 394 resorption have also been suggested as differentiation mechanisms for the trachytes (White et $395 a l ., 2009)$ and there is petrographic evidence for such a process in our samples, such as modal 396 alkali feldspar abundances up to 40\% (Figs. 3 (a), (b)). Values higher than $\sim 1300$ ppm Ba and $397 \mathrm{Eu} / \mathrm{Eu}^{*} \approx 1.36$ have been observed only in whole-rock trachyte analyses, strongly suggesting 398 that those samples have been affected by such processes.

399 This raises the question as to the composition of the least evolved trachytic melt in the 400 Green Tuff. This is important because it helps to define the liquid-line-of-descent from 401 intermediate to salic compositions. Williams et al. (2014) presented LA-ICP-MS analyses of 402 trachytic glass with $59.90 \mathrm{wt} \% \mathrm{SiO}_{2}$ and $251 \mathrm{ppm} \mathrm{Zr}$. All analyses in their data set with 
403 positive $\mathrm{Eu}$ anomalies have about the same $\mathrm{SiO}_{2}$ and $\mathrm{Zr}$ contents. That may well represent,

404 therefore, the trachytic melt parental to the comenditic trachytes.

405 Chlorine values range continuously from below detection $(\sim 250 \mathrm{ppm})$ in some trachytic 406 glasses to $1.2 \mathrm{wt} \%$ (with an outlier at $1.73 \mathrm{wt} \%$ ) in the pantellerites. Abundances are

407 positively correlated with $\mathrm{SiO}_{2}$ and $\mathrm{Zr}$, indicating progressive enrichment with increased

408 fractionation. Civetta et al. (1988), Lowenstern (1994), Gioncada \& Landi (2010) and Lanzo

409 et al. (2013) noted that $\mathrm{Cl}$ abundances increase more quickly than $\mathrm{Zr}$ in glass in various

410 Pantescan suites, suggesting an upward enrichment mechanism in the reservoir. They also

411 suggested that the fact that $\mathrm{Cl}$ levels reached $\sim 1 \mathrm{wt} \%$ and then remained constant during

412 further magma evolution, as measured by increases in $\mathrm{SiO}_{2}$ and $\mathrm{Zr}$, pointed to separation of a

413 Cl-bearing fluid phase with which the magmas remained in equilibrium. The new Green Tuff

414 data apparently show a continuing increase of $\mathrm{Cl}$ with fractionation, suggesting that $\mathrm{Cl}$

415 remained in the melt phase.

416 Sulphur abundances $\left(\right.$ as $\left.\mathrm{SO}_{3}\right)$ range from below detection $(\sim 0.03 \mathrm{wt} \%)$ to $0.21 \mathrm{wt} \%$,

417 although the great majority of analyses are $<0.1 \mathrm{wt} \%$. These values agree with values for

418 Pantescan rocks given by Civetta et al. (1988), Lowenstern (1994), Gioncada \& Landi (2010),

419 Neave et al. (2012) and Lanzo et al. (2013). Abundances show a positive, but scattered,

420 correlation with increasing peralkalinity; it is not clear whether the scatter is due to loss of S

421 on devitrification or to variable loss of a magmatic volatile phase.

422 An important feature of the glass analyses is the range of compositions within individual

423 samples, shown by the $\mathrm{SiO}_{2}$ and $\mathrm{Zr}$ ranges in Table 1, denoting the mingling in varying

424 combinations of trachytic and rhyolitic melts. The range within samples varies from 2 to $9 \mathrm{wt}$

$425 \% \mathrm{SiO}_{2}$ and its size is not related to the whole-rock composition. Two examples of the mixing

426 components are shown in Fig. 10. In Fig. 10 (a), a fragment of pale glass with a $\mathrm{SiO}_{2}$ content 18 
427 of $72-73$ wt $\%$ contains irregular dark blebs with lower $\mathrm{SiO}_{2}$ contents $(65-68$ wt \%). The

428 photograph of a thin section of 150521(Fig. 10 (b)) shows textural intermingling of darker and 429 lighter glass components with $\mathrm{SiO}_{2}$ values varying from $\sim 67-71 \mathrm{wt} \%$. Texturally different 430 glasses in the same specimen do not always show such significant compositional differences.

431 For example, the pale and dark glasses shown in Fig. 4 (a) have $\mathrm{SiO}_{2}$ in the ranges 68.7-70.3 432 and 67.9-70.1 $\mathrm{wt} \%$, respectively.

433

\section{GEOCHEMICAL MODELS}

Major-element mass balance models were developed to test the fractional and equilibrium crystallization hypotheses for the origin of compositional zoning and to constrain the relative proportion of the phases involved (Table 4). All calculations were managed with Microsoft Office Excel 2013 and are considered acceptable if $\Sigma r^{2}<1.0$. The first model (A) tests the origin of highly evolved pantellerite glass from comenditic trachyte matrix glass. The most primitive comenditic trachyte glass analyzed for this study was recovered from sample 150522, and has the lowest P.I. (1.09) and $\mathrm{FeO}^{*}$ (4.3 wt \%) and highest $\mathrm{Al}_{2} \mathrm{O}_{3}(16.1 \mathrm{wt} \%)$ observed; this was chosen as the model parent for Part A. Zirconium concentrations were below the detection limit of the electron probe for this sample. The model daughter selected is an evolved matrix glass at the intersection of two sub-trends recovered from sample 150514 with P.I. $=1.96,9.5 \mathrm{wt} \% \mathrm{FeO}^{*}, 7.3 \mathrm{wt} \% \mathrm{Al}_{2} \mathrm{O}_{3}$ and $2591 \mathrm{ppm} \mathrm{Zr}$.

A second, similar model (B) tests the origin of highly evolved pantellerite melt inclusions hosted in alkali feldspar from sample 150514 with a P.I. $=2.61,10 \mathrm{wt} \% \mathrm{FeO} *, 5.3 \mathrm{wt} \%$ $\mathrm{Al}_{2} \mathrm{O}_{3}$, and 2961 ppm Zr. Both models use a mineral assemblage from sample 150511, which has a composition intermediate between the model parent and daughter. Model results are 19 
450 both acceptable $\left(\Sigma \mathrm{r}^{2}=0.255\right.$ and 0.240 , respectively) and very similar, suggesting that these

451 highly evolved melts can be produced by $93-94 \%$ fractional crystallization of an assemblage

452 dominated by alkali feldspar (92.5\%) with subordinate clinopyroxene and olivine (2.5-3\%

453 each), ilmenite $(\sim 1.5 \%)$, and apatite $(<1 \%)$. This model is largely in agreement with previous

454 models of fractional crystallization of the peralkaline trachyte-pantellerite suite at Pantelleria,

455 but also presents the highest estimate for degree of fractional crystallization. The model of

456 White et al. (2009), for example, suggested 70\% fractional crystallization, but from a more

457 peralkaline parent $(\mathrm{P} . \mathrm{I} .=1.12,7.0 \% \mathrm{FeO} *)$ to a less peralkaline daughter $(\mathrm{PI}=1.91,7.8 \%$

458 FeO*). However, this and other models (e.g. Civetta et al., 1998; Neave et al., 2012) all agree

459 on a dominant role for alkali feldspar ( $>85 \%$ of the fractionating assemblage), with

460 subordinate olivine, clinopyroxene, Fe-Ti oxide, and apatite, consistent with the observed

461 mineral assemblages in these samples. Although we lack $\mathrm{Zr}$ data for the comenditic trachyte

462 glass, Williams et al. (2014) report an average value of $255 \mathrm{ppm}$ for one glass sample within

463 the comenditic trachyte facies of the Green Tuff type section; if we assume bulk $\mathrm{D}_{\mathrm{Zr}} \approx 0$, then

$464 \quad \mathrm{~F}=0.09-0.10(91-90 \%$ crystallization $)$ which is consistent with our results.

465 A curious feature observed in Fig. 7 is a sub-horizontal trend at $\sim 7.5$ wt $\% \mathrm{Al}_{2} \mathrm{O}_{3}$ (Trend

466 3B) that extends from the end of the main trend (modelled in Part A) to progressively lower

467 concentrations of $\mathrm{FeO}^{*}$ that nonetheless include glasses with the highest concentrations of $\mathrm{Zr}$

468 measured (up to 3108 ppm) despite near-uniform Zr whole-rock concentrations (1500-1700

$469 \mathrm{ppm})$. This trend is also manifest in Figures 11 and $12 \mathrm{~b}$ (next section), where these samples

470 appear to plot along the experimental alkali feldspar-quartz cotectic (Carmichael \&

471 MacKenzie, 1963). These highly evolved samples have assemblages characterized by a

472 relatively large volume of aenigmatite (e.g. 2-3\% in 150514), along with quartz, alkali

473 feldspar and clinopyroxene; we suggest that this trend is the result of equilibrium 


\begin{abstract}
474 crystallization of this assemblage. Mass balance modelling of this scheme (Table 4, Part C)
475 suggests its plausibility $\left(\sum r^{2}=0.655\right.$, with 0.221 error from $\left.\mathrm{MnO}\right)$, with a small degree $(8 \%)$

476 of late crystallization of an assemblage of aenigmatite and quartz with minor quantities of

477 alkali feldspar and sodian clinopyroxene resulting in a decrease in $\mathrm{FeO}^{*}$ with a slight rise in

$478 \mathrm{Al}_{2} \mathrm{O}_{3}$ and P.I. An estimate of the degree of crystallization from $\mathrm{Zr}$ ratios (assuming $\mathrm{D}_{\mathrm{Zr}} \approx 0$,

479 as above) between the model daughter and parent suggest about twice as much crystallization

$480 \quad(17 \%, \mathrm{~F}=0.83)$ as that determined by major-element mass balance modelling.

481 Overall, the results of the modelling are consistent with the various magmas having been 482 formed by fractional crystallization of the observed phenocryst assemblages.
\end{abstract}

\section{GEOTHERMOMETRY}

485

In Fig. 11, temperatures calculated by (a) QUILF (olivine + clinopyroxene) and (b) by clinopyroxene - glass and clinopyroxene - whole-rock (Putirka et al., 2003) (Table 5) are

487 plotted against Zr contents in the whole-rocks. While the QUILF results yield higher 488 temperatures at given $\mathrm{Zr}$ content, it is clear that the least evolved trachytes give $\sim 900^{\circ} \mathrm{C}$ and 489 the temperatures then decrease to $\sim 700^{\circ} \mathrm{C}$ in the most peralkaline members. There must, of 490 course, have been local temperature fluctuations due to mixing of magmas from different 491 bars of pressure, silica activity changes by only 0.02 units and temperature increases (or 
497 decreases) by only $3^{\circ} \mathrm{C}$ on average. However, oxygen fugacity, relative to the FMQ buffer,

498 remains relatively unchanged.

499 Whole-rock (a) and glass (b) analyses have been plotted in the system Q-Ab-Or- $\mathrm{H}_{2} \mathrm{O}$ with 8.3 mol\% 500 aegirine +8.3 mol\% sodium metasilicate added, $\mathrm{P}_{\mathrm{H} 2 \mathrm{O}}=1000$ bar, and projected from $\mathrm{H}_{2} \mathrm{O}+$ aegirine + 501 sodium metasilicate (Carmichael \& MacKenzie, 1963) (Fig. 12). The normative mineralogy was 502 calculated with $\mathrm{FeO} / \mathrm{FeO}^{*}=0.9$, corresponding to oxygen fugacities buffered at FMQ-1 between 700 503 and $900^{\circ} \mathrm{C}$ (Sack et al., 1980). The alkali feldspar liquidus surface is plotted as crosses, labelled with 504 the experimentally determined temperature $\left({ }^{\circ} \mathrm{C}\right)$ for that composition. The minimum for this system 505 occurs at $\mathrm{Q}_{40.5} \mathrm{Or}_{34.5} \mathrm{Ab}_{25}$, with the alkali feldspar-quartz cotectic located at approximately $\mathrm{Q}_{40}$. Also 506 shown is the "thermal valley" of Carmichael \& MacKenzie (1963), the differentiation path of a system 507 undergoing crystal fractionation of alkali feldspar with a composition of $\sim \mathrm{Or}_{35}$. Despite some scatter, 508 temperatures drop from $825^{\circ} \mathrm{C}$ in the trachytes to $700^{\circ} \mathrm{C}$ in the most peralkaline whole-rocks, 509 temperatures consistent with those found in Fig. 11, and the rocks generally follow a feldspar 510 fractionation trend. The spread of glass compositions at $\mathrm{Or}_{40}$ is consistent with some melts having 511 reached the quartz-feldspar cotectic.

512 The vertical decrease in temperature from the comenditic trachyte to the pantellerite is accompanied 513 by an increase in silica activity relative to quartz saturation $\left(a \mathrm{SiO}_{2}(\mathrm{Qtz})\right)$, calculated by QUILF95, 514 from 0.74 to 1.0 , as well as a slight increase in oxygen fugacity relative to the FMQ buffer (Fig. 13).

515 Macdonald et al. (2011) described the antipathetic relationship between fayalitic olivine and 516 aenigmatite as a function of $\mathrm{T}, \mathrm{P}$ and $a \mathrm{SiO}_{2}$, with the latter crystallizing at the expense of the former at $517 \mathrm{~T}<750^{\circ} \mathrm{C}$ at silica activities close to or at quartz saturation at $150 \mathrm{MPa}$. Lower pressures extend the 518 stability of aenigmatite to higher temperatures (cf. White et al., 2005; Di Carlo et al., 2010) which is 519 consistent with these results.

520 Fayalite-bearing rhyolites with ilmenite present as the sole Fe-Ti oxide phase crystallize in T- $f \mathrm{O}_{2}$ 521 space along the displaced FHQ (fayalite-hematite-quartz) buffer. In this sense, the FHQ buffer is 522 "displaced" from that which would plot for unit activities for all phases. A regression through the T22 


\begin{abstract}
$523 a \mathrm{SiO}_{2}$ data was used to calculate the displaced FHQ buffer for ilmenite compositions between $X_{\mathrm{ilm}}$
5240.95 and 0.98 in Fig. 13. In our formulation, unit activity is assumed only for fayalite and the curve is

525 displaced to lower $f \mathrm{O}_{2}$ due to much lower hematite activities $\left(X_{\mathrm{hem}}=0.03-0.05\right.$; activities calculated

526 following Andersen \& Lindsley, 1988) and silica activities relative to quartz saturation less than one

527 (interpolated from the linear trend in the previous figure, with silica activities calculated from olivine-

528 clinopyroxene equilibrium using QUILF95).
\end{abstract}

529 The Green Tuff broadly follows the FHQ curve, with the magma chamber becoming slightly less 530 reduced roofward relative to the FMQ buffer. A comparison with experimental data from pantelleritic

531 systems, including Eburru, Kenya (Scaillet \& Macdonald, 2006) and Pantelleria (Di Carlo et al., 532 2010), suggests that this may be due to a corresponding volatile gradient from $\sim 1 \mathrm{wt} \% \mathrm{H}_{2} \mathrm{O}$ in the 533 comenditic trachyte to $\sim 4 \mathrm{wt} \% \mathrm{H}_{2} \mathrm{O}$ in the pantellerite. The presence of such a volatile gradient may 534 be supported by FTIR analyses of melt inclusions in the basal pantellerite and uppermost trachyte. 535 Melt inclusions in the trachyte are comenditic trachyte in composition, with $0.15-1.05 \mathrm{wt} \% \mathrm{H}_{2} \mathrm{O}$ 536 (Romano et al., submitted). Lanzo et al. (2013) reported values of up to $4.2 \mathrm{wt} \% \mathrm{H}_{2} \mathrm{O}$ from feldspar537 hosted melt inclusions in the pantelleritic basal fall unit, consistent with values from melt inclusions in 538 compositionally similar pantellerite lavas (up to $4.9 \mathrm{wt} \% \mathrm{H}_{2} \mathrm{O}$; Gioncada \& Landi, 2010; Neave et al., 539 2012).

540 Using the model parameters of White et al. (2009), the simplest explanation for a volatile 541 gradient is $\sim 70 \%$ fractional crystallization of a comenditic trachyte melt with $1.0-1.5 \mathrm{wt} \%$ $542 \mathrm{H}_{2} \mathrm{O}$, which would produce a pantellerite melt with 3.3-4.9 wt $\% \mathrm{H}_{2} \mathrm{O}$ (assuming bulk $\mathrm{D}_{\mathrm{H}_{2} \mathrm{O}}=$ 543 0.01). This in turn would require $0.3-0.5 \mathrm{wt} \% \mathrm{H}_{2} \mathrm{O}$ in the parental basalts - lower than either 544 the 0.9-1.6 wt \% reported by Gioncada \& Landi (2010) for melt inclusions in the Cuddie 545 Rosse basalt or the 1.0-1.5 wt \% predicted from MELTS modelling (White et al., 2009).

546 Experimental results on Pantescan basalts also suggest that they must be hydrous ultimately to 547 produce pantelleritic melts (Scaillet et al., 2005), although the MELTS results reported by

548 White et al. (2009) suggest that basalt water concentrations as low as $0.5 \mathrm{wt} \%$ would also 23 
549 produce similar comenditic trachyte. The volatile gradient and accompanying change in

550 oxidation state could also be explained by melt vesiculating, which could result in a reaction

551 between Fe-rich silicate melt and $\mathrm{H}_{2} \mathrm{O}$ via thermal dissociation and degassing of $\mathrm{H}_{2}$ (cf.

552 Carmichael, 1991; Mungall \& Martin, 1995; Scaillet \& Macdonald, 2001; White et al., 2005).

553

554

555

556

557

558

559

560

561

562

563

564

565

566

567

568

569

570

571

572

\section{DISCUSSION}

\section{Nature of Green Tuff reservoir}

Possible relationships in the plumbing system prior to the eruption of the Green Tuff are shown in Fig. 17. A magma reservoir is envisaged with a trachytic crystal mush overlain by a layered pantelleritic upper part of the chamber. Pressure estimates of $100 \mathrm{MPa}$, which correspond to depths of 3-4 km, were used for all thermodynamic calculations because (1) this is in between the total range of 50-150 MPa estimated by previous workers for the depth of the magma chamber using various methods, and (2) this depth is consistent with geophysical studies of the depth of the magma chamber, e.g. with the model of Mattia et al. (2007), based on geodetic data, placing the top of the reservoir at $\sim 4 \mathrm{~km}$ beneath the caldera. The overall depth of the reservoir would have been greater if the Montagna Grande trachytes were part of the magma system; they were erupted from lower layers in the reservoir during resurgence following eruption of the Green Tuff, although the depth of magma being tapped is not known. Major element contents are consistent with such a cogenetic relationship (Fig. 8 (a)) and, although trace element data are rather scarce for Montagna Grande, the trace elements are also consistent; average $\mathrm{Zr} / \mathrm{Nb}$ ratios, for example, are 4.9 in the Green Tuff and 4.5 in the Montagna Grande trachytes. The speculative gabbroic mush represents the source of the trachytic magmas, squeezed out either by compaction or buoyancy. 
573 Similar models for trachyte - peralkaline rhyolite relationships have been proposed by

574 Troll \& Schmincke (2001) for ignimbrite 'A', Gran Canaria, and by Sumner \& Wolff (2003)

575 for the 'TL' ignimbrite, Gran Canaria.

576

577 Origin of compositional zonation

578 Previous authors have used geochemical modelling to show that the transition from trachyte

579 to rhyolite at Pantelleria can be satisfactorily modelled by fractionation of an alkali feldspar-

580 olivine-clinopyroxene-oxide \pm aenigmatite assemblage (Civetta et al., 1988; White et al.,

581 2009; Neave et al., 2012). The new models presented here are consistent with these earlier

582 models. Experimental studies of Pantescan rocks by Di Carlo et al. (2010) and Romano et al.

583 (2018) are also consistent with such models. We propose, therefore, that the comenditic

584 trachytes separated from the crystal-rich metaluminous trachytes later erupted as the

585 Montagna Grande Trachyte. Continued fractional crystallization of the trachytic magmas

586 generated pantelleritic melts which separated from the trachytes through buoyancy effects and

587 accumulated towards the roof of the reservoir, finding levels determined by their density.

588 Some of the compositional variation in the Green Tuff has also been related to alkali

589 feldspar accumulation (Korringa \& Noble, 1972; Prosperini et al., 1990; White et al., 2009).

590 For example, the so-called low-incompatible trace element (low-ITE) trachytes of White et al.

591 (2009) were shown to contain up to $47 \%$ modally of alkali feldspar phenocrysts. The new data

592 set provides further evidence that the process was important in the evolution of the Green

593 Tuff. For example, at $\sim 300 \mathrm{ppm} \mathrm{Zr}$, the Eu anomaly increases from 1 to 1.6 (Fig. 14). At the

594 same $\mathrm{Zr}$ value, $\mathrm{K} / \mathrm{Rb}$ ratios rise from $\sim 600$ to 1000 , Ba contents from $\sim 700-2300 \mathrm{ppm}$ and $\mathrm{Sr}$

595 contents from $\sim 50$ to $70 \mathrm{ppm}$, features consistent with feldspar accumulation in the trachytic

596 rocks. Major- and trace- element models presented by White et al. (2009) and Romano et al. 
597 (2018) suggest that samples affected by accumulation or resorption of alkali feldspar will

598 have $\mathrm{Ba}>1300 \mathrm{ppm}$. The process was also locally operative at higher levels in the chamber;

599 sample 150541, with $\sim 35$ modal\% feldspar phenocrysts, has high $\mathrm{Al}_{2} \mathrm{O}_{3}, \mathrm{Ba}$ and $\mathrm{Sr}$ (Fig. 8)

600 contents. However, it has a negative Eu anomaly $\left(\mathrm{Eu} / \mathrm{Eu}^{*} 0.54\right)$ which would require that the

601 accumulating feldspar had a negative anomaly. Yet Mahood \& Stimac (1990) argued that all

602 the feldspars in the Green Tuff have strong positive Eu anomalies.

603 It appears, therefore, that the composition of the comenditic trachyte underlying the

604 pantellerites was modified by variable amounts of feldspar accumulation.

605

606 Glass heterogeneity and implications for syneruptive mixing

607 Density variations in the melts (glasses) have been calculated by the method of Bottinga \&

608 Weill (1970) (Fig. 15). Anhydrous densities range from $2480 \mathrm{~kg} \mathrm{~m}^{-3}$ in the trachytes to 2420

$609 \mathrm{~kg} \mathrm{~m}^{-3}$ in the most peralkaline melts. This might imply that the pantelleritic part of the

610 reservoir was stably density-stratified while the higher density and viscosity of the feldspar-

611 rich trachytes prevented them from rising and mixing with the overlying rhyolites. This

612 further implies that eruption of the Green Tuff was triggered by an external mechanism. We

613 suggest that the trigger was an influx of more mafic magma into the trachytic parts of the

614 reservoir which raised temperatures (as seen in the resorption of phenocrysts) and caused

615 trachytic melts to rise and mix with the overlying more evolved melts (c.f. Flude et al., 2008;

616 Romengo et al., 2012). Triggering of the eruption of peralkaline magmas by intrusion of

617 intermediate magmas has been proposed by Sumner \& Wolff (2003) for ignimbrite 'TL'

618 (Gran Canaria) and by Pimentel et al. (2016) for comenditic trachytes of the AD 1761

619 eruption at Terceira Island (Azores). The lack of significant compositional zoning in the

620 resorbed phenocrysts is taken to show that the more mafic magma acted as a heat source 26

http://www.petrology.oupjournals.org/ 
621 without physical or chemical mixing, as discussed by D'Oriano et al. (2017) for similar

622 feldspar-rich zones for comenditic trachytes of the Lajes ignimbrite eruption, Terceira Island, 623 Azores

624 Models of magma evacuation from compositionally zoned chambers have shown how each 625 successive evacuation draws magma from progressively deeper levels of the chamber, 626 isochemical surfaces being deflected upwards beneath the vents so that several compositional 627 layers can be tapped simultaneously (Blake, 1981; Blake \& Ivey, 1986; Spera et al., 1986; 628 Schuraytz et al., 1989; Macdonald et al., 1994). It was noted earlier that many Green Tuff 629 samples show a range of matrix glass compositions, denoting the mingling in varying 630 combinations of trachytic and rhyolitic melts. Importantly, the mingling was very thorough, 631 down to the micron scale, which we ascribe to the small differences in temperature and 632 density between the pantelleritic melts which did not significantly hinder mixing.

633 The range of $\mathrm{SiO}_{2}$ values in the glasses is matched by variations in $\mathrm{Zr}$ (Table 1). It appears, 634 therefore, that the steady increase in $\mathrm{Zr}$ values shown with increasing height in the pre635 eruptive chamber by Williams et al. (2014) does not simply reflect an increasing degree of 636 fractionation of the melt upwards. Rather, it reflects an increasing proportion of evolved melts 637 in earlier erupted magma batches. Plotting the highest $\mathrm{Zr}$ value in each sample, as a measure 638 of the sample's highest stratigraphic position within the pre-eruptive chamber, against the 639 range of $\mathrm{Zr}$ contents in the same glasses, two broad zones can be distinguished (Fig. 16): (i) a 640 zone where the glasses all have rather homogeneous (?) trachytic composition; and (ii) a zone 641 where the glasses are dominantly mixes of rhyolitic-rhyolitic melts. Two barriers to mixing 642 thus existed in the system: one between crystal-rich and crystal-poor comenditic trachytes and 643 one between the trachytes and pantellerites. 
644 An important general point arising from the within-sample ranges in glass composition is

645 that whole-rock analyses do not necessarily give a true indication of the range of melt

646 compositions in the pre-eruptive reservoir; as noted above, the highest whole-rock and glass

$647 \mathrm{Zr}$ values are 2300 and $3183 \mathrm{ppm}$, respectively. This raises the question as to how common

648 this type of fine-scale mingling may be in compositionally zoned silicic systems. Clearly,

649 relevant studies would preferably need to be made in systems preserving significant glassy

650 facies. However, in their absence a careful analysis of the stability relationships of the

651 phenocryst assemblages should provide clues as to the range of host melts.

652

653 Significance for the Daly Gap

654 Models for the formation of the Pantescan suite are broadly divisible into two groups. In one,

655 the trachytes and rhyolites were formed independently of basaltic magma; intermediate

656 compositions (mugearites and benmoreites) are the products of magma mixing (Lowenstern \&

657 Mahood, 1991; Avanzinelli et al., 2004; Ferla \& Meli, 2006; Romengo et al., 2012). In the

658 other model, the salic rocks were formed by the prolonged crystal fractionation of basaltic

659 magma. The observed scarcity or absence of intermediate rocks results from either a physical

660 or thermodynamic discrimination in the magma reservoirs and their non-eruption (Civetta et

661 al., 1988; White et al., 2009; Neave et al., 2012). One aim of this paper has been to assess

662 whether melts of intermediate composition were present in the Green Tuff magma system.

663 Some of the published evidence is equivocal. Geochemical modelling had shown that the

664 pantellerites of Pantelleria could have been produced by $\sim 95 \%$ fractional crystallization of

665 parental alkali basalts, via magmas of intermediate composition. In the modelling of White et

666 al. (2009), melts entered the Daly gap $\left(\sim 50-62 \mathrm{wt} \% \mathrm{SiO}_{2}\right)$ after $30 \%$ crystallization, and then

667 stayed there for a further 59\% crystallization. In contrast, in experiments made on a Pantescan 28 
668 basalt at $1 \mathrm{~atm}$ and $8 \mathrm{~kb}$, Mahood \& Baker (1986) found that residual melts had not reached 669 the Daly gap after $70 \%$ crystallization.

670 The main approach used here was to carefully relate glass and mineral compositions to 671 textures. The least evolved glass composition in the new Green Tuff data set has $62.84 \mathrm{wt} \%$ $672 \mathrm{SiO}_{2}$; similar glass compositions $\left(\mathrm{SiO}_{2} 59.90-62.3 \mathrm{wt} \%\right)$ have been recorded in the Green 673 Tuff by Mahood \& Stimac (1990) and Williams et al. (2014). No clearly intermediate674 composition melts have thus been found.

675 As an indicator of what mineral compositions might be expected, in their MELTS 676 modelling of the evolution of Pantescan suites White et al. (2009) found the following 677 mineral compositions as melts passed through the benmoreite stage (at $1.0 \% \mathrm{H}_{2} \mathrm{O}$ in the 678 parent, $100 \mathrm{MPa}$, FMQ-1): plagioclase $\mathrm{An}_{60-49}$; olivine $\mathrm{Fo}_{47-21}$; clinopyroxene $\mathrm{Wo}_{45} \mathrm{En}_{35-30} \mathrm{Fs}_{20-}$

679 25. For this study, a careful analysis was made of the cores of phenocrysts in the Green Tuff, 680 on the basis that they may have preserved compositions from earlier stages of magma 681 evolution. For feldspar, the most "mafic" composition was $\mathrm{An}_{7.9}$; for olivine $\mathrm{Fo}_{25.4}$; for 682 clinopyroxene $\mathrm{En}_{29}$. The main phenocryst phases thus crystallized from melts more evolved 683 than benmoreite.

684 White et al. (2009) described, from post-caldera trachyte lavas of Montagna Grande and 685 Monte Gibele, anorthoclase phenocrysts $\left(\mathrm{An}_{3-9} \mathrm{Ab}_{70-71} \mathrm{Or}_{20-26}\right)$ with cores of resorbed 686 plagioclase $\left(\mathrm{An}_{34} \mathrm{Ab}_{62} \mathrm{Or}_{4}\right)$. A benmoreitic lava from Montagna Grande, thought to have 687 formed by mixing of trachytic and mafic magmas, contains feldspar phenocrysts with 688 resorbed cores of plagioclase $\left(\mathrm{An}_{43-32} \mathrm{Ab}_{53-63} \mathrm{Or}_{3-5}\right)$ mantled by oligoclase $\left(\mathrm{An}_{23-25} \mathrm{Ab}_{66-67} \mathrm{Or}_{9-}\right.$ 689 11) (Romengo et al., 2012). The occurrence of such calcic compositions as cores suggests that 690 the feldspars initially crystallized from magmas of intermediate composition and were being 691 resorbed during subsequent melt evolution. It is possible that if the Montana Grande trachytes 29 
692 were part of the Green Tuff magma system (Mahood \& Hildreth, 1986), benmoreitic magmas 693 may have been trapped in these lower, dense and viscous levels in the chamber and could not 694 rise into the part erupted as the Green Tuff. Many post-Green Tuff pantelleritic eruptives have 695 abundant trachytic enclaves (Prosperini et al., 1990; Ferla \& Meli, 2006; Landi \& Rotolo, 696 2015), implying ready intrusion of trachyte to high-levels in these systems. This suggests a 697 remarkable efficiency for the trachyte "trap" zone in the Green Tuff reservoir. It may be noted 698 that Mattia et al. (2007) suggested that trapping of benmoreitic and mugearitic magmas in the 699 chamber due to their relatively high density compared to the more peralkaline rocks and 700 contributed to the high values of the Bouguer anomaly.

701 In summary, possible relationships in the plumbing system prior to the eruption of the 702 Green Tuff are shown in Fig. 17. The upper part of the erupted reservoir is compositionally 703 zoned pantellerite magma, underlain by feldspar-phyric trachyte. The crystal-rich colourless 704 layer would be erupted during resurgence as the Montagna Grande lavas. The gabbroic mush 705 represents the source of the trachytic magmas, squeezed out either by compaction or 706 buoyancy.

707

708 CONCLUSIONS

709 (1) The Green Tuff was erupted from a magma reservoir compositionally zoned from 710 pantellerite (top) to comenditic trachyte (bottom). Conditions within the reservoir are 711 estimated to have been temperature $\sim 900-700{ }^{\circ} \mathrm{C}, f \mathrm{O}_{2} \mathrm{FMQ}-1.5$ to FMQ-0.5 and $a \mathrm{SiO}_{2}$ (relative to 712 quartz saturation) 0.74-1.00. 
1

2

3

4

5

6

7

8

9

713 (2) The trachytic layer was rich in alkali feldspar phenocrysts and overlay the densely-phyric

714 Montagna Grande Trachyte, which was erupted during resurgence of the caldera whose

715 formation accompanied eruption of the Green Tuff.

716 (3) Prior to eruption, the Green Tuff magma was layered by crystal fractionation of alkali

717 feldspar- olivine-clinopyroxene-Fe-Ti oxide- apatite assemblages.

718 (4) During eruption, mingling between layers, especially in the pantellerites, was ubiquitous, 719 at scales down to the micron level, a process revealed only by detailed analysis of within720 sample glasses. Whole-rock analyses mask the significance of the mixing.

721 (5) The new glass analyses have significantly extended the range of melt compositions in the 722 tuff, to those approaching the effective minimum composition for peralkaline silicic melts of 723 Macdonald et al. (2012).

724 (6) Phenocrysts in the comenditic trachyte are commonly heavily resorbed but only slightly 725 zoned compositionally, indicating perhaps that they were heated by, but did not mix, with 726 influxes of intermediate magmas which were trapped in a lower layer.

\section{ACKNOWLEDGEMENTS}

729 We thank Lidia Jeżak for help with the electron microprobe analyses. Wes LeMasurier, David

730 Neave, Silvio Rotolo and Editor Gerhard Wörner provided extremely detailed and helpful

731 reviews of the manuscript.

732

733

734

\section{REFERENCES}

Andersen, D.J. \& Lindsley, D.H. (1988) Internally consistent solution models for Fe-Mg-Mn-Ti 
735

736

737

738

739

740

741

742

743

744

745

746

747

748

749

750

751

752

753

754

755

oxides. American Mineralogist 73, 714-726.

Andersen, D.J., Lindsley, D.H. \& Davidson, P.M. (1993). QUILF: a PASCAL program to assess equilibria among Fe-Mg-Mn-Ti oxides, pyroxenes, olivine, and quartz. Computers and Geosciences 19, 1333-1350.

Avanzinelli, R., Bindi, L., Menchetti, S. \& Conticello, S. (2004). Crystallization and genesis of peralkaline magmas from Pantelleria Volcano, Italy: an integrated petrological and crystal-chemical study. Lithos 73, 41-69.

Bagiński, B., Macdonald, R., White, J.C. \& Jeżak, L. (2018). Tuhualite in a peralkaline rhyolitic ignimbrite from Pantelleria, Italy. European Journal of Mineralogy. DOI: 10.1127/ejm/2018/00302711.

Baker, B.H. \& Henage, I.F. (1977). Compositional changes during crystallization of some peralkaline silicic lavas of the Kenya Rift Valley. Journal of Volcanology and Geothermal Research 2, 17-28.

Behncke, B., Berrino, G., Corrado, G. \& Velardita, R. (2006). Ground deformation and gravity changes on the island of Pantelleria in the geodynamic framework of the Sicily Channel. Journal of Volcanology and Geothermal Research 150, 146-162.

Blake, S. (1981). Eruptions from zoned magma chambers. Journal of the Geological Society, London 138, 281-287.

Blake, S. \& Ivey, G.N. (1986). Magma mixing and the dynamics of withdrawal from stratified reservoirs. Journal of Volcanology and Geothermal Research 27, 153-178.

Bottinga, Y. \& Weill, D.F. (1970). Densities of liquid silicate systems calculated from partial molar volumes of oxide components. American Journal of Science 269, 169-182.

32 
756 Calò, M. \& Parisi, L. (2014). Evidences of a lithospheric fault zone in the Sicily Channel

757 continental rift (southern Italy) from instrumental seismicity data. Geophysical Journal

$758 \quad$ International 199, 219-225.

759 Carmichael, I.S.E. (1991).The redox states of basic and silicic magmas: a reflection of their source

760 regions? Contributions to Mineralogy and Petrology 106, 129-141.

761 Carmichael, I.S.E. \& Mackenzie, W.S. (1963). Feldspar-liquid equilibria in pantellerites: an

762 experimental study. American Journal of Science 261, 382-396.

763 Catalano, S., Tortorici, L. \& Viccaro, M. (2014). Regional tectonic control on large size explosive

764 eruptions: Insights into the Green Tuff ignimbrite unit of Pantelleria. Journal of Geodynamics 73,

$765 \quad 223-233$.

766 Chapman, D.S. \& Pollack, H.N. (1975). Global heat flow: A new look. Earth and Planetary Science

$767 \quad$ Letters 28, 23-32.

768 Civetta, L., Cornette, Y., Crisci, G., Gillot, P.Y., Orsi, G. \& Reqeujo, C.S. (1984). Geology,

769 geochronology and chemical evolution of the island of Pantelleria. Geological Magazine 121, 541-

$770 \quad 562$.

771 Civetta, L., Cornette, Y., Gillot, P.Y. \& Orsi, G. (1988). The eruptive history of Pantelleria (Sicily

772 Channel) in the last 50 ka. Bulletin of Volcanology 50, 47-57.

773 Civetta, L., D’Antonio, M., Orsi, G. \& Tilton, G.R. (1998). The geochemistry of volcanic rocks from

774 Pantelleria island, Sicily channel: Petrogenesis and characteristics of the mantle source region.

775 Journal of Petrology 39, 1453-1491. 
776 Civile, D., Lodolo, E., Tortorici, L., Lanzafame, G. \& Brancolini, G. (2008). Relationships between

777 magmatism and tectonics in a continental rift: the Pantelleria Island region (Sicily Channel, Italy).

778 Marine Geology 251, 32-46.

779 Della Vedova, B., Lucazeau, F., Pasquale, V., Pellis, G. \& Verdoya, M. (1995). Heat flow in the

780 tectonic provinces crossed by the southern segment of the European Geotraverse. Tectonophysics

$781244,57-74$.

782 Di Carlo, I., Rotolo, S., Scaillet, B., Buccheri, V. \& Pichavant, M. (2010). Phase equilibrium

783 constraints on pre-eruptive conditions of recent explosive volcanism of Pantelleria Island, Italy.

784 Journal of Petrology 51, 2245-2276.

785 D’Oriano, C., Landi, P., Pimentel, A. \& Zanon, V. (2017). Magmatic processes revealed by

786 anorthoclase textures and trace element modelling: The case of the Lajes Ignimbrite eruption

787 (Terceira Island, Azores). Journal of Volcanology and Geothermal Research 347, 44-63.

788 Esperança, S. \& Crisci, G.M. (1995). The island of Pantelleria: A case for the development of DMM-

789 HIMU isotopic compositions in a long-lived extensional setting. Earth and Planetary Science

$790 \quad$ Letters 136, 167-182.

791 Ferla, P. \& Meli, C. (2006). Evidence of magma mixing in the 'Daly Gap' of alkaline suites: a case

792 study from the enclaves of Pantelleria (Italy). Journal of Petrology 47, 1467-1502.

793 Flude, S., Burgess, R. \& McGarvie, D.W. (2008). Silicic volcanism at Ljósufjöll, Iceland: Insights into

794 evolution and eruptive history from Ar-Ar dating. Journal of Volcanology and Geothermal

$795 \quad$ Research 169, 154-175.

34

http://www.petrology.oupjournals.org/ 
1

2

3

4

5

6

7

8

9

10
796

797

798

799

800

801

802

803

804

805

806

807

808

809

810

811

812

813

814

815

Frost, B.R., Lindsley, D.H. \& Andersen, D.J. (1988). Fe-Ti oxide-silicate equilibria: assemblages with fayalitic olivine. American Mineralogist 73, 727-740.

Fulignati, P., Malfitano, G. \& Sbrana, A. (1997). The Pantelleria caldera geothermal system: Data from the hydrothermal minerals. Journal of Volcanology and Geothermal Research 75, 251-270.

Gantar, C., Morelli, C., Segre, A. \& Zampieri, L. (1961). Studio gravimetrico e considerazioni geologiche sull'isola di Pantelleria. Bollettino Geofisica Teorica e Applicata 3, 267-287.

Gioncada, A. \& Landi, P. (2010). The pre-eruptive volatile contents of recent basaltic and pantelleritic magmas at Pantelleria (Italy). Journal of Volcanology and Geothermal Research 189, 191-201.

Jordan, N.J., Rotolo, S.G., Williams, R., Speranza, F., McIntosh, W.C., Branney, M.J. \& Scaillet, S. (2018). Explosive eruptive history of Pantelleria, Italy: Repeated caldera collapse and ignimbrite emplacement at a peralkaline volcano. Journal of Volcanology and Geothermal Research 349, 4773.

Korringa, M.K. \& Noble, D.C. (1972). Genetic significance of chemical, isotopic, and petrographic features of some peralkaline salic rocks from the island of Pantelleria. Earth and Planetary Science Letters 17, 258-262.

Kovalenko, V.I., Naumov, V.B., Solovova, I.P., Girnis, A.V., Hervig, R.L. \& Boriani, A. (1994). Volatile components, composition, and crystallization conditions of the Pantelleria basaltpantellerite association magmas, inferred from the melt and fluid inclusion data. Petrology 2, 19-34.

Kunzmann, T. (1999). The aenigmatite-rhönite mineral group. European Journal of Mineralogy 11, 743-756. 35 
816 Landi, P. \& Rotolo, S.G. (2015). Cooling and crystallization recorded in trachytic enclaves hosted in

817 pantelleritic magmas (Pantelleria, Italy): Implications for pantellerite petrogenesis. Journal of

$818 \quad$ Volcanology and Geothermal Research 301, 169-179.

819 Lanzo, G., Landi, P. \& Rotolo, S.G. (2013). Volatiles in pantellerite magmas: A case study of the

820 Green Tuff Plinian eruption (Island of Pantelleria). Journal of Volcanology and Geothermal

$821 \quad$ Research 262, 153-163.

822 Le Maitre, R.W. (Ed.) (2002). A classification of igneous rocks and glossary of terms.

823 Recommendations of the International Union of Geological Sciences Subcommission on the

824 Systematics of Igneous Rocks. Second Edition. Cambridge University Press, Cambridge.

825 Lowenstern, J.B. (1994). Chlorine, fluid immiscibility, and degassing in peralkaline magmas from

826 Pantelleria, Italy. American Mineralogist 79, 353-369.

827 Lowenstern, J.B. \& Mahood, G.A. (1991). New data on magmatic $\mathrm{H}_{2} \mathrm{O}$ contents of pantellerites, with

828 implications for petrogenesis and eruptive dynamics at Pantelleria. Bulletin of Volcanology 54, 78-

82983.

830 Macdonald, R. (1974). Nomenclature and petrochemistry of the peralkaline oversaturated extrusive

831 rocks. Bulletin Volcanologique 38, 498-516.

832 Macdonald, R., Bagiński, B., Belkin, H.E., Dzierżanowski, P. \& Jeżak, L. (2008).

833 Compositional variations in apatite from a benmoreite - peralkaline rhyolite volcanic suite,

834 Kenya Rift Valley. Mineralogical Magazine 72, 1147-1161. 


\author{
835 Macdonald, R., Bagiński, B., Leat, P.T, White, J.C. \& Dzierżanowski, P. (2011). Mineral stability in \\ 836 peralkaline silicic rocks: Information from trachytes of the Menengai volcano, Kenya. Lithos 125, \\ $837 \quad 553-568$. \\ 838 Macdonald, R., Bagiński, B., Ronga, F., Dzierżanowski, P., Lustrino, M., Marzoli, A. \& Melluso, L. \\ 839 (2012). Evidence for extreme fractionation of peralkaline silicic magmas, the Boseti volcanic \\ 840 complex, Main Ethiopian Rift. Mineralogy and Petrology 104, 163-175. \\ 841 Macdonald, R., Navarro, J.M., Upton, B.G.J. \& Davies, G.R. (1994). Strong compositional zonation in \\ 842 peralkaline magma: Menengai, Kenya Rift Valley. Journal of Volcanology and Geothermal \\ $843 \quad$ Research 60, 301-325.
}

844 Mahood, G.A. (1984). Pyroclastic rocks and calderas associated with strongly peralkaline magmatism.

$845 \quad$ Journal of Geophysical Research 89, 8540-8552.

846 Mahood, G.A. \& Baker, D.R. (1986). Experimental constraints on depths of fractionation of mildly

847 alkalic basalts and associated felsic rocks: Pantelleria, Strait of Sicily. Contributions to Mineralogy

$848 \quad$ and Petrology 93, 251-264.

849 Mahood, G.A. \& Hildreth, W. (1986). Geology of the peralkaline volcano at Pantelleria, Strait

$850 \quad$ of Sicily. Bulletin of Volcanology 48, 143-172.

851 Mahood, G.A. \& Stimac, J.A. (1990). Trace-element partitioning in pantellerites and

852 trachytes. Geochimica et Cosmochimica Acta 54, 2257-2276.

853 Margari, V., Pyle, D.M., Bryant, C. \& Gibbard, P.L. (2007). Mediterranean tephra

854 stratigraphy revisited: results from a long terrestrial sequence on Lesvos Island, Greece. 
856 Mattia, M., Bonaccorso, A. \& Guglielmino, F. (2007). Ground deformations in the Island of

857 Pantelleria (Italy): Insights into the dynamics of the current intereruptive period. Journal of $858 \quad$ Geophysical Research 112, B11406.

859 Morelli, C., Gantar, C. \& Pisani, M. (1975). Bathymetry, gravity and magnetism in the Straits

860 of Sicily and Ionian Sea. Bolletino di Geofisica Teorica ed Applicata 17, 39-58.

861 Mungall, J.E. \& Martin, R.F. (1995). Petrogenesis of basalt-comendite and basalt-pantellerite

862 suites, Terceira, Azores, and some implications for the origin of ocean-island rhyolites.

863 Contributions to Mineralogy and Petrology 119, 43-55.

864 Neave, D.A., Fabbro, G., Herd, R.A., Petrone, C.M. \& Edmonds, M. (2012). Melting,

865 differentiation and degassing at the Pantelleria volcano, Italy. Journal of Petrology 53, 637-

866663.

867 Noble, D.C. (1967). Sodium, potassium, and ferrous iron contents of some secondarily

868 hydrated natural silicic glasses. American Mineralogist 52, 280-286.

869 Noble, D.C. (1970). Loss of sodium from crystallized comendite welded tuffs of the Miocene 870 Grouse Canyon Member of the Belted Range Tuff, Nevada. Geological Society of America $871 \quad$ Bulletin $\mathbf{8 1}, 2677-2687$.

872 Noble, D.C., Smith, V.C. \& Peck, L.C. (1967). Loss of halogens from crystallized and glassy 38 
873 silicic volcanic rocks. Geochimica et Cosmochimica Acta 31, 215-223.

874 Orsi, G. \& Sheridan, M.F. (1984). The Green Tuff of Pantelleria: rheoignimbrite or

875 rheomorphic fall? Bulletin of Volcanology 47, 611-626.

876 Orsi, G., Gallo, G. \& Zanchi, A. (1991). Simple-shearing block resurgence in caldera

877 depressions. A model from Pantelleria and Ischia. Journal of Volcanology and Geothermal

$878 \quad$ Research 47, 1-11.

879 Pimentel, A., Zanon, V., de Groot, L.V., Hipólito, A., Di Chiara, A. \& Self, S. (2016). Stress-

880 induced comenditic trachyte effusion triggered by trachybasalt intrusion: multidisciplinary

881 study of the AD 1761 eruption at Terceira Island (Azores). Bulletin of Volcanology 78, 22.

882 Pouchou, J.L. \& Pichoir, J.F. (1991). Quantitative analysis of homogeneous or stratified

883 microvolumes applying the model 'PAP'. In: Heinrich, K.F.J. \& Newbury, D.E. (eds)

884 Electron Probe Quantification. Plenum Press, New York, 31-75.

885 Prosperini, N., Perugini, D., Poli, G. \& Manetti, P. (1990). Magmatic enclaves distribution

886 within the Khaggiar lava dome (Pantelleria, Italy): implications for magma chamber

887 dynamics and eruption. Acta Vulcanologica 12, 37-47.

888 Putirka, K.D., Mikaelian, H., Ryerson, F. \& Shaw, H. (2003). New clinopyroxene-liquid

889 thermobarometers for mafic, evolved, and volatile-bearing lava compositions, with

890 applications to lavas from Tibet and the Snake River Plain, Idaho. American Mineralogist 
891

892

893

894

895

896

897

898

899

900

901

902

903

904

905

906

907

908

88, 1542-1554.

Romano, P., Andújar, J., Scaillet, B., Romengo, N., di Carlo, I. \& Rotolo, S.G. (2018).

Phase equilibria of Pantelleria trachytes (Italy): constraints on pre-eruptive conditions and on the metaluminous to peralkaline transition in silicic magmas. Journal of Petrology 59, 559-588.

Romano, P., White, J.C., Ciulla, A., Di Carlo, I., D’Oriano, C.D., Landi, P. \& Rotolo, S.G. (submitted). Volatile and trace element content in melt inclusions from the zoned Green Tuff ignimbrite (Pantelleria, Sicily): petrological inferences. Submitted to Annals of Geophysics.

Romengo, N., Landi, P. \& Rotolo, S.G. (2012). Evidence of basaltic magma intrusions in a trachytic magma chamber at Pantelleria (Italy). Periodico di Mineralogia 81, 163-178.

Sack, R.O., Carmichael, I.S.E., Rivers, M. \& Ghiorso, M.S. (1980). Ferric-ferrous equilibria in natural silicate liquids at 1 bar. Contributions to Mineralogy and Petrology 75, 369-376.

Scaillet, B. \& Macdonald, R. (2001). Phase relations of peralkaline silicic magmas and petrogenetic implications. Journal of Petrology 42, 825-845.

Scaillet, B. \& Macdonald, R. (2003). Experimental constraints on the relationships between peralkaline rhyolites of the Kenya Rift Valley. Journal of Petrology 94, 1867-1894.

Scaillet, B. \& Macdonald, R. (2006). Experimental constraints on pre-eruptive conditions of 40 
909 pantelleritic magmas: Evidence from the Eburru complex, Kenya Rift. Lithos 91, 95-108.

910 Scaillet, B., Macdonald, R., Buccheri, V., Rotolo, S.G. \& Pichavant, M. (2005). Phase

911 equilibrium constraints on the production and storage of peralkaline silicic magmas:

912 insights from Kenya and Pantelleria. Peralkaline rocks: Sources, economic potential and

913 evolution from alkaline melts (M. Marks, ed.). Workshop on peralkaline rocks, Tübingen,

914 Germany.

915 Scaillet, S., Rotolo, S.G., La Felice, S. \& Vita-Scaillet, G. (2011). High-resolution ${ }^{40} \mathrm{Ar} /{ }^{39} \mathrm{Ar}$

916 chronostratigraphy of the post-caldera $(<20 \mathrm{ka})$ volcanic activity at Pantelleria, Sicily

917 Strait. Earth and Planetary Science Letters 309, 280-290.

918 Scaillet, S., Vita-Scaillet, G. \& Rotolo, S.G. (2013). Millenial-scale phase relationships between ice-

919 core and Mediterranean marine records: insights from high-precision ${ }^{40} \mathrm{Ar} /{ }^{39} \mathrm{Ar}$ dating of the Green

920 Tuff of Pantelleria, Sicily Strait. Quaternary Science Reviews 78, 141-154.

921 Schuraytz, B.C., Vogel, T.A. \& Younker, L.W. (1989). Evidence for dynamic withdrawal from a

922 layered magma body: The Topopah Spring Tuff, southwestern Nevada. Journal of Geophysical

$923 \quad$ Research 94, 5925-5942.

924 Spera, F.J., Yuen, D.A., Greer, J.C. \& Sewell, G. (1986). Dynamics of magma withdrawal from

925 stratified magma chambers. Geology 14, 723-726.

926 Sumner, J.M. \& Wolff, J. (2003). Petrogenesis of mixed-magma, high-grade, peralkaline ignimbrite

927 'TL' (Gran Canaria): diverse styles of mixing in a replenished, zoned magma chamber. Journal of 41 
929 Sun, S.-S. \& McDonough, W.F. (1989). Chemical and isotopic systematics of oceanic basalts:

930 implications for mantle composition and processes. Magmatism in the Ocean Basins (A.D.

931 Saunders \& M.J. Norry, eds.) Geological Society Special Publication 42, 313-345.

932 Troll, V.R. \& Schmincke, H.-U. (2002). Magma mixing and crustal recycling recorded in ternary

933 feldspar from compositionally zoned peralkaline ignimbrite 'A', Gran Canaria, Canary Islands.

934 Journal of Petrology 43, 243-270.

935 Verzhbitsky, E.V. \& Kononov, M.V. (2003). Heat flow and origin of the lithosphere in the central

936 Mediterranean region. Geotectonics 37, 328-336.

937 Villari, L. (1974). The island of Pantelleria. Bulletin of Volcanology 38, 680-724.

938 Weaver, S.D., Gibson, I.L., Houghton, B.F. \& Wilson, C.J.N. (1990). Mobility of rare earth

939 and other elements during crystallization of peralkaline silicic lavas. Journal of

$940 \quad$ Volcanology and Geothermal Research 43, 57-70.

941 White, J.C., Holt, G.S., Parker, D.F. \& Ren, M. (2003). Trace-element partitioning between

942 alkali feldspar and peralkalic quartz trachyte to rhyolite magma. Part 1: Systematics of

943 trace-element partitioning. American Mineralogist 88, 316-329.

944 White, J.C., Ren, M. \& Parker, D.F. (2005). Variation in mineralogy, temperature, and

945 oxygen fugacity in a suite of strongly peralkaline lavas and tuffs, Pantelleria, Italy. The

946 Canadian Mineralogist 43, 1331-1347.

42 
947 White, J.C., Parker, D.F. \& Ren, M. (2009). The origin of trachyte and pantellerite from

948 Pantelleria, Italy: Insights from major element, trace element, and thermodynamic

949 modelling. Journal of Volcanology and Geothermal Research 179, 33-55.

950 Williams, R., Branney, M.J. \& Barry, T.L. (2014). Temporal and spatial evolution of a

951 waxing then waning catastrophic density current revealed by chemical mapping. Geology

$952 \quad 42,107-110$.

953 Wolff, J.A. \& Wright, J.V. (1981). Formation of the Green Tuff, Pantelleria. Bulletin of

$954 \quad$ Volcanology 44, 681-690.

955 Wright, J.V. (1980). Stratigraphy and geology of the welded air-fall tuffs of Pantelleria.

956 Geologisches Rundschau 69, 263-291.

957

$958 \quad$ Figure captions

959

960 Figure 1. Locality map showing the distribution of the Green Tuff ignimbrite and the rim

961 faults of the La Vecchia and Cinque Denti calderas. Sample localities are marked. Simplified

962 from Scaillet et al. (2011).

963

964 Figure 2. Vertical section through the Green Tuff pumice fall and ignimbrite at the type

965 locality on the Monastero scarp (Fig. 1) where it is $\sim 7.5 \mathrm{~m}$ thick. Modified from Williams et

966 al. (2014). The trachytic component is found in the rheomorphic vitrophyre at the top of the

967 deposit (wavy lines). Approximate positions of our samples within the stratigraphy are shown. 43 
969 Figure 3. Resorption of phenocrysts in trachytic host rocks. (a) Sieve-texture in alkali

970 feldspar (Kfs). The small phenocryst is fayalite (Ol). Sample 150522. (b) Heavily resorbed

971 alkali feldspar in 150513. Note the darkening and incipient devitrification of the glass (Gl)

972 around the crystal (arrowed). (c) Fayalite phenocryst (Ol), with apatite (Ap) inclusion. The

973 crystal partially includes a magnetite microphenocryst (Mag). Sample 150513. (d) Partially

974 resorbed hedenbergite phenocryst (Cpx: 150513), containing inclusions of apatite and

975 magnetite. The associated phenocryst is fayalite, completely replaced by magnetite + quartz.

976 Note the darkening and incipient devitrification of the glass around the crystal. Details of the

977 samples are given in the Appendix.

978

979 Figure 4. Different styles of magma mixing in the Green Tuff. Samples: (a) Round blebs of 980 dark glass embedded in pale brown glass. Alkali feldspar crystals (Kfs) occur in both types.

981 Sample 150513. (b) Densely welded tuff with intermingled dark brown and pale fiamme.

982 Sample 150551. (c) Densely welded type with mingling of at least two varieties of glass.

983 Sample 150543. (d) A less densely welded sample shows pale and slightly deeper brown

984 glasses streakily intermingled along their junction. A euhedral aenigmatite phenocryst is

985 marked (Aen). Sample 150544. Details of the samples are given in the Appendix.

987 Figure 5. $(\mathrm{Si}+\mathrm{Na})$ plotted against $(\mathrm{Al}+\mathrm{Ca})$ for aenigmatite phenocrysts in the Green Tuff. 988 New data from this paper, Electronic Appendix 2 (a); literature data from Mahood \& Stimac 989 (1990), White et al. (2009) and Neave et al. (2012).

990 
991 Figure 6. Plots of the FK/A index $\left(\mathrm{mol}\left(\mathrm{FeO}^{*}+\mathrm{K}_{2} \mathrm{O}\right) / \mathrm{Al}_{2} \mathrm{O}_{3}\right)$ versus the peralkalinity index

992 (P.I. $\left.=\mathrm{mol}\left(\mathrm{Na}_{2} \mathrm{O}+\mathrm{K}_{2} \mathrm{O}\right) / \mathrm{Al}_{2} \mathrm{O}_{3}\right)$ to test for potential sodium loss in peralkaline rocks (White $e t$ 993 al., 2003). (a) Whole-rock compositions, with potentially altered samples labelled. Data from 994 Table 2. (b) Glass analyses in individual samples (listed). Data from Electronic Appendix 3.

Figure 7. Whole-rocks (WR) and glass (all symbols except + and $x$ ) for Green Tuff plotted in 997 the classification scheme for peralkaline silicic rocks of Macdonald (1974). CT, comenditic 998 trachyte; C, comendite; PT, pantelleritic trachyte; P, pantellerite. TS - analyses for whole999 rocks from the type section of the Green Tuff from Williams et al. (2014). Trends 1 to 3 1000 reflect changing fractionating assemblages; see text for details. The trend marked Di Carlo is 1001 for experimental glasses in the study of a Pantescan pantellerite by Di Carlo et al. (2010).

1002 Data sources: whole rocks (WR) - Table 2, this paper, Mahood \& Stimac (1990), White et al. 1003 (2009); glass - this paper, Electronic Appendix 3, Mahood \& Stimac (1990; samples 7, 226 1004 and 231/233) and Neave et al. (2012; sample 09PNL033).

1005

Figure 8. (a) Selected major element v. $\mathrm{SiO}_{2}$ plots for Green Tuff whole-rocks. The ranges of 1007 glass analyses are shown as fields. (b) Selected trace element v. $\mathrm{SiO}_{2}$ plots. Data from this 1008 paper, Table 2, Electronic Appendix 3, and White et al. (2009, samples 060537 and 060545). 1009 The arrowed sample (150541) in the $\mathrm{Al}_{2} \mathrm{O}_{3}$ and Ba plots is thought to be slightly feldspar1010 accumulitic. Also shown in both plots are whole-rock analyses of trachytes from Montagna 1011 Grande and Monte Gibele (data from Villari (1974), Mahood \& Hildreth (1986), Avanzinelli 1012 et al. (2004), Ferla \& Meli (2006) and White et al. (2009)). The field for MgO in glass has 1013 been drawn omitting two anomalously high analyses. 
1015 Figure 9. Chondrite-normalized REE plots for (a) whole-rocks and (b) glasses. Normalizing 1016 factors from Sun \& McDonough (1989). Data sources: whole-rocks, this paper, Table 2, and 1017 Mahood \& Stimac (1990, sample 231); glass, patterns 3 and 5, Mahood \& Stimac (1990; 1018 samples 226 and 231), pattern 2, Neave et al. (2012; sample 09PNL033) and patterns 1 and 4, 1019 Williams et al. (2014; samples 44E and 44H). Glass patterns 4 and 5 are comenditic trachyte, 1020 patterns 1,2 and 3 are pantelleritic.

1021

Figure 10. Examples of different styles of magma mixing in the Green Tuff. Values are for $\mathrm{SiO}_{2} \mathrm{wt} \%$. (a) Streaky intermingling of glass ranging in composition from $\sim 67$ to $71 \mathrm{wt} \%$ $\mathrm{SiO}_{2}$. Sample 150551. (b) Fragment of pale brown glass in very dark brown host. Sample 1025 150521. (c) The composition of the pale glass in (b) ranges from 66 to $73 \mathrm{wt} \% \mathrm{SiO}_{2}$.

1026

1027

Figure 11. (a) Comparison of calculated temperatures $\left({ }^{\circ} \mathrm{C}\right)$ for whole-rock compositions and

1028

1029

1030

1031

1032

1033 assemblages plotted against Zr concentration. QUILF95 points are calculated from olivineclinopyroxene equilibria (Andersen et al., 1993). CPX-WR are calculated from clinopyroxene-whole rock compositions (Putirka et al., 2003). KFS were determined from the position of the whole rock composition in Fig. 12 (see text for details). (b) Comparison of calculated temperatures for glass compositions plotted against $\mathrm{Zr}$ concentration, determined with the techniques described for (a). Averages with error bars are plotted for CPX and individual points are plotted for KFS to facilitate 1034 readability. 
1036

1037

1038

1039

1040

1041

1042

1043

1044

1045

1046

1047

1048

1049

1050

1051

1052

1053

1054

1055

1056

1057

1058

1059

Figure 12. (a) Whole-rock and (b) glass analyses plotted in the system Q-Ab-Or- $\mathrm{H}_{2} \mathrm{O}$ with $8.3 \mathrm{~mol} \%$ aegirine $+8.3 \mathrm{~mol} \%$ sodium metasilicate added and $\mathrm{P}_{\mathrm{H} 2 \mathrm{O}}=1000$ bar. (Carmichael \& MacKenzie, 1963). Whole rock analyses displayed include those presented in this study (Table 2) and from the literature (Civetta et al., 1984, 1989; Kovalenko et al., 1994; Esperança \& Crisci, 1995; Avanzinelli et al., 2004; Ferla \& Meli, 2006; White et al., 2009; Williams et al., 2014). The crosses mark the alkali feldspar liquidus surface.

Figure 13. (a) Silica activity $\left(a \mathrm{SiO}_{2}\right)$ relative to quartz saturation and (b) oxygen fugacity relative to the FMQ buffer plotted against temperature. W09-GT and W-O9-TR are the results of QUILF95 geothermobarometry for the Green Tuff and Montagna Grande Trachyte, respectively, from White et al. (2009). The fayalite-ilmenite-aenigmatite stability curve for $X_{\mathrm{Ilm}}=0.95$ is calculated following Macdonald et al. (2011), with ilmenite activities calculated with the solution model of Andersen \& Lindsley (1988). $\triangle \mathrm{FMQ}=\log f \mathrm{O}_{2}-\mathrm{FMQ}(\mathrm{T})$, with FMQ(T) calculated following Frost et al. (1988).

(c) The experimental results of Scaillet \& Macdonald (2006) for Eburru and Di Carlo et al. (2010) for Pantelleria show the strong positive correlation between oxygen fugacity (as $\Delta \mathrm{FMQ})$ and melt water content (wt \% $\mathrm{H}_{2} \mathrm{O}_{\text {melt }}$ ).

Figure 14. Eu/Eu* plotted against $\mathrm{Zr}$ content for Green Tuff samples. Data sources: wholerocks - this paper, Table 2; Mahood \& Stimac (1990); White et al. (2009); glass - Mahood \& Stimac (1990, samples 7, 226, 231/233), Neave et al. (2012, sample 09PNL033), Williams et al. (2014, samples 44H and 44I).

Figure 15. Anhydrous melt densities, calculated by the method of Bottinga \& Weill (1970), plotted against $\mathrm{Zr}$ contents for whole-rocks (open circles) and glasses (closed circles). The densities initially 47 
1060 decrease to $\mathrm{Zr} \sim 1500 \mathrm{ppm}$ and then change little with increasing $\mathrm{Zr}$. Data sources: this paper, Table 2

1061 and Electronic Appendix 3.

1062

1063 Figure 16. Maximum $\mathrm{Zr}$ content in glass in each Green Tuff whole-rock plotted against range

1064 of $\mathrm{Zr}$ contents in glass of same rock. The ranges indicate mixing in varying proportions of

1065 trachytic and rhyolitic melts. Also shown is the composition of a Montagna Grande glass,

1066 from Mahood \& Stimac (1990, sample 119); its relative compositional similarity to the

1067 Montagna Grande whole-rocks suggests that the range of glasses in each sample must be

1068 small. Montagna Grande whole-rock data from Mahood \& Stimac (1990), Avanzinelli et al.

1069 (2004), Ferla \& Meli (2006) and White et al. (2009).

1070

1071 Figure 17. Possible relationships in the magmatic plumbing system prior to eruption of the

1072 Green Tuff. The crustal structure is from Civile et al. (1988). 


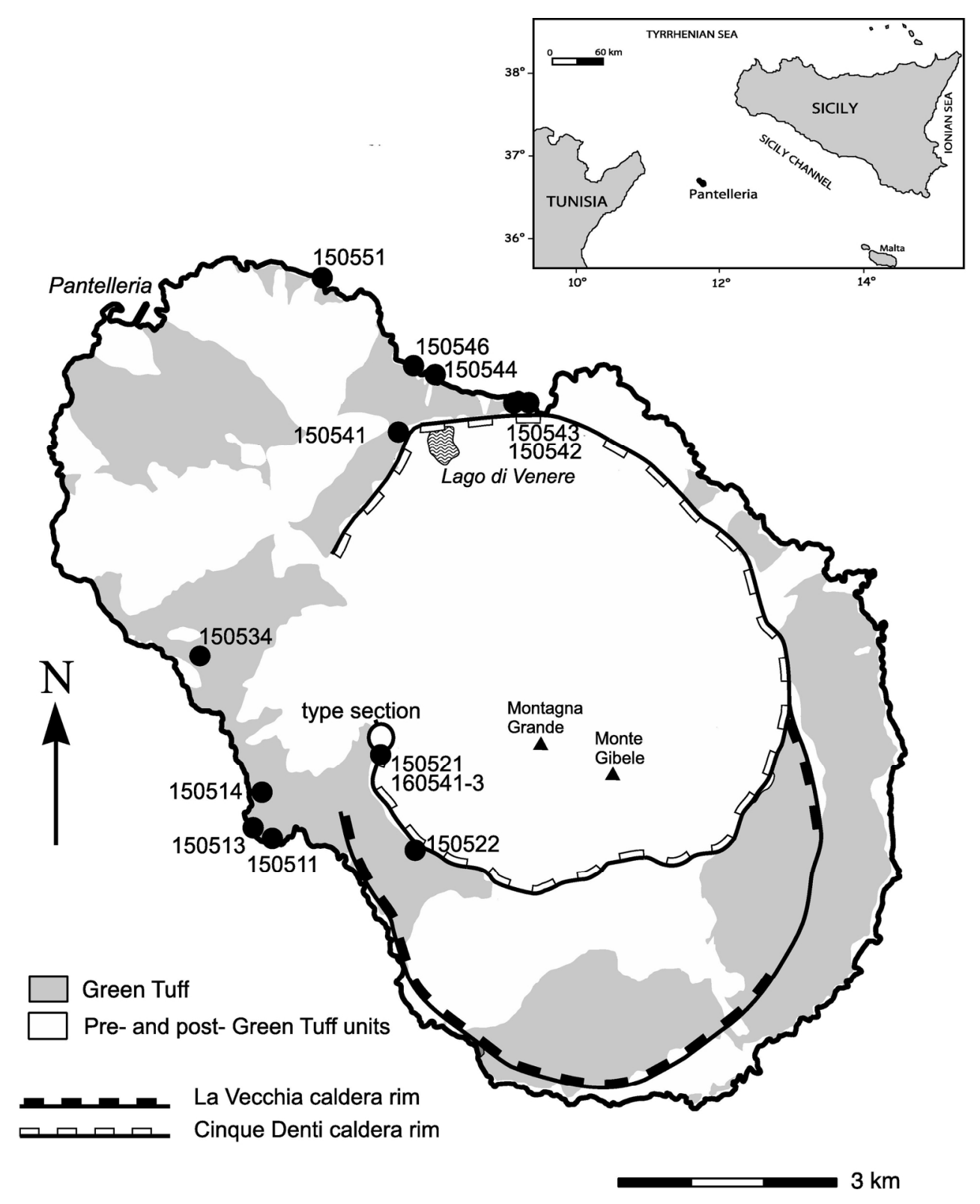

Figure 1. Locality map showing the distribution of the Green Tuff ignimbrite and the rim faults of the La Vecchia and Cinque Denti calderas. Sample localities are marked. Simplified from Scaillet et al. (2011). $166 \times 204 \mathrm{~mm}(300 \times 300 \mathrm{DPI})$ 
Figure 2. Vertical section through the Green Tuff pumice fall and ignimbrite at the type locality on the Monastero scarp (Fig. 1) where it is $\sim 7.5$ m thick. Modified from Williams et al. (2014). The trachytic component is found in the rheomorphic vitrophyre at the top of the deposit (wavy lines). Approximate positions of our samples within the stratigraphy are shown.

$190 \times 340 \mathrm{~mm}(300 \times 300$ DPI $)$ 


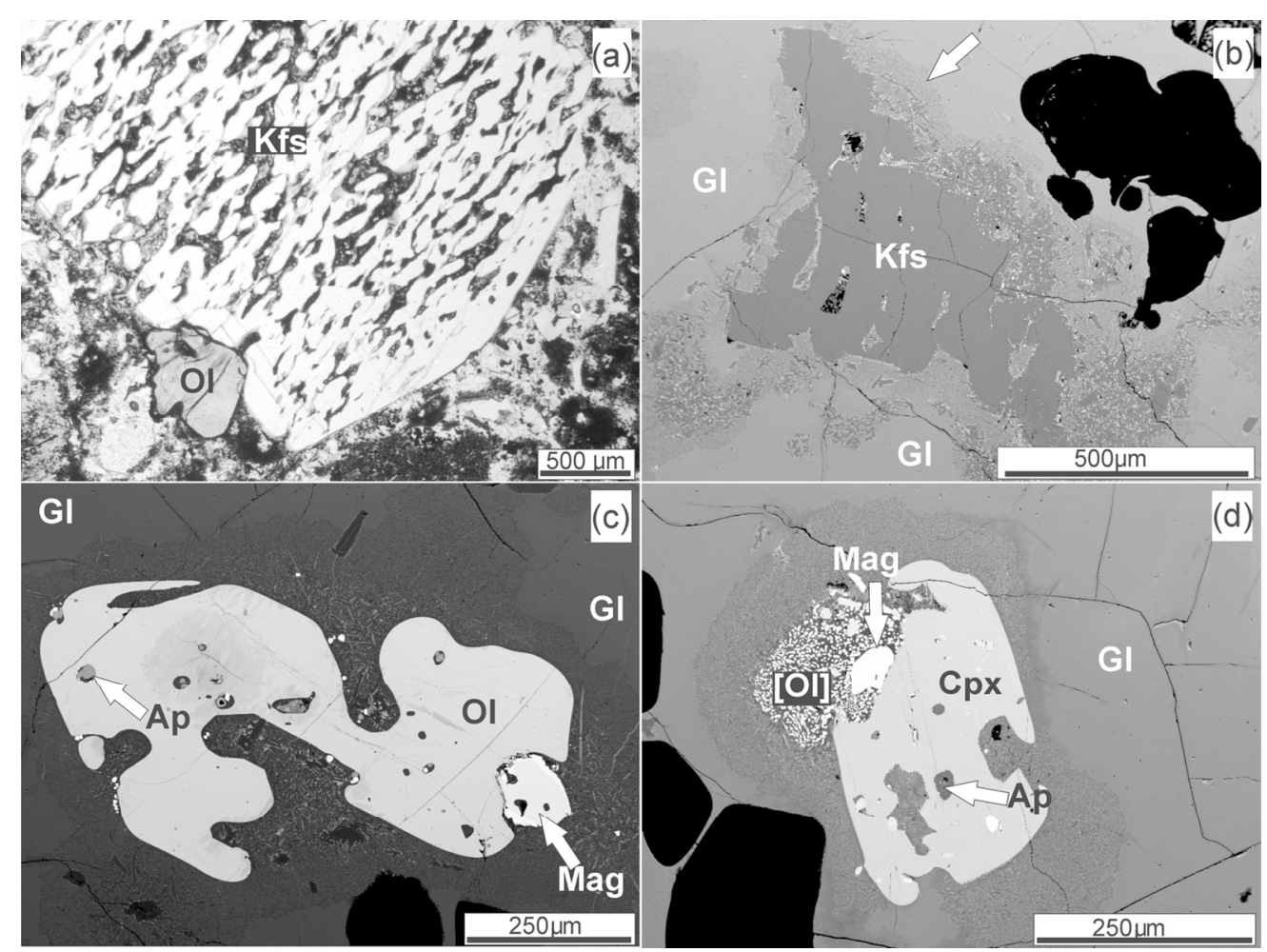

Figure 3. Resorption of phenocrysts in trachytic host rocks. (a) Sieve-texture in alkali feldspar (Kfs). The small phenocryst is fayalite (OI). Sample 150522. (b) Heavily resorbed alkali feldspar in 150513 . Note the darkening and incipient devitrification of the glass (Gl) around the crystal (arrowed). (c) Fayalite phenocryst $(\mathrm{Ol})$, with apatite (Ap) inclusion. The crystal partially includes a magnetite microphenocryst (Mag). Sample 150513. (d) Partially resorbed hedenbergite phenocryst (Cpx: 150513), containing inclusions of apatite and magnetite. The associated phenocryst is fayalite, completely replaced by magnetite + quartz. Note the darkening and incipient devitrification of the glass around the crystal. Details of the samples are given in the Appendix. 


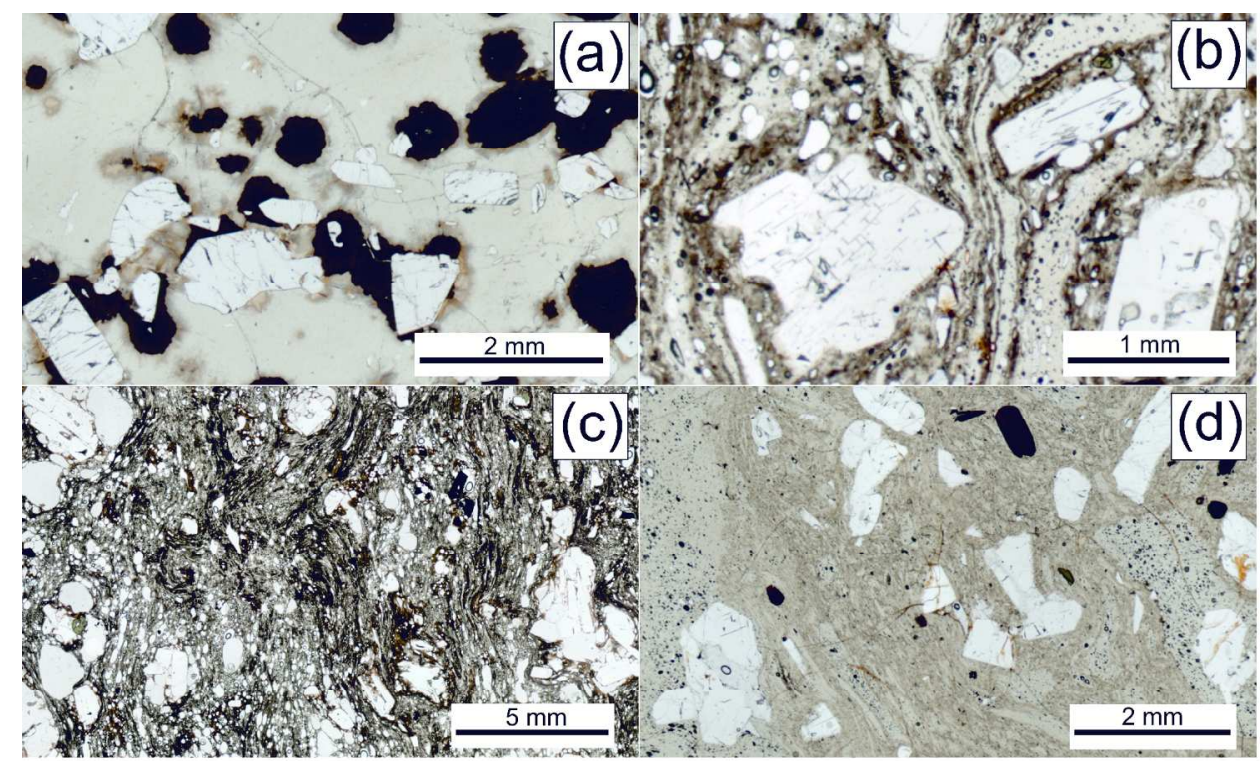

Figure 4. Different styles of magma mixing in the Green Tuff. Samples: (a) Round blebs of dark glass embedded in pale brown glass. Alkali feldspar crystals (Kfs) occur in both types. Sample 150513. (b) Densely welded tuff with intermingled dark brown and pale fiamme. Sample 150551. (c) Densely welded type with mingling of at least two varieties of glass. Sample 150543. (d) A less densely welded sample shows pale and slightly deeper brown glasses streakily intermingled along their junction. A euhedral aenigmatite phenocryst is marked (Aen). Sample 150544. Details of the samples are given in the Appendix.

$186 \times 116 \mathrm{~mm}(300 \times 300 \mathrm{DPI})$ 


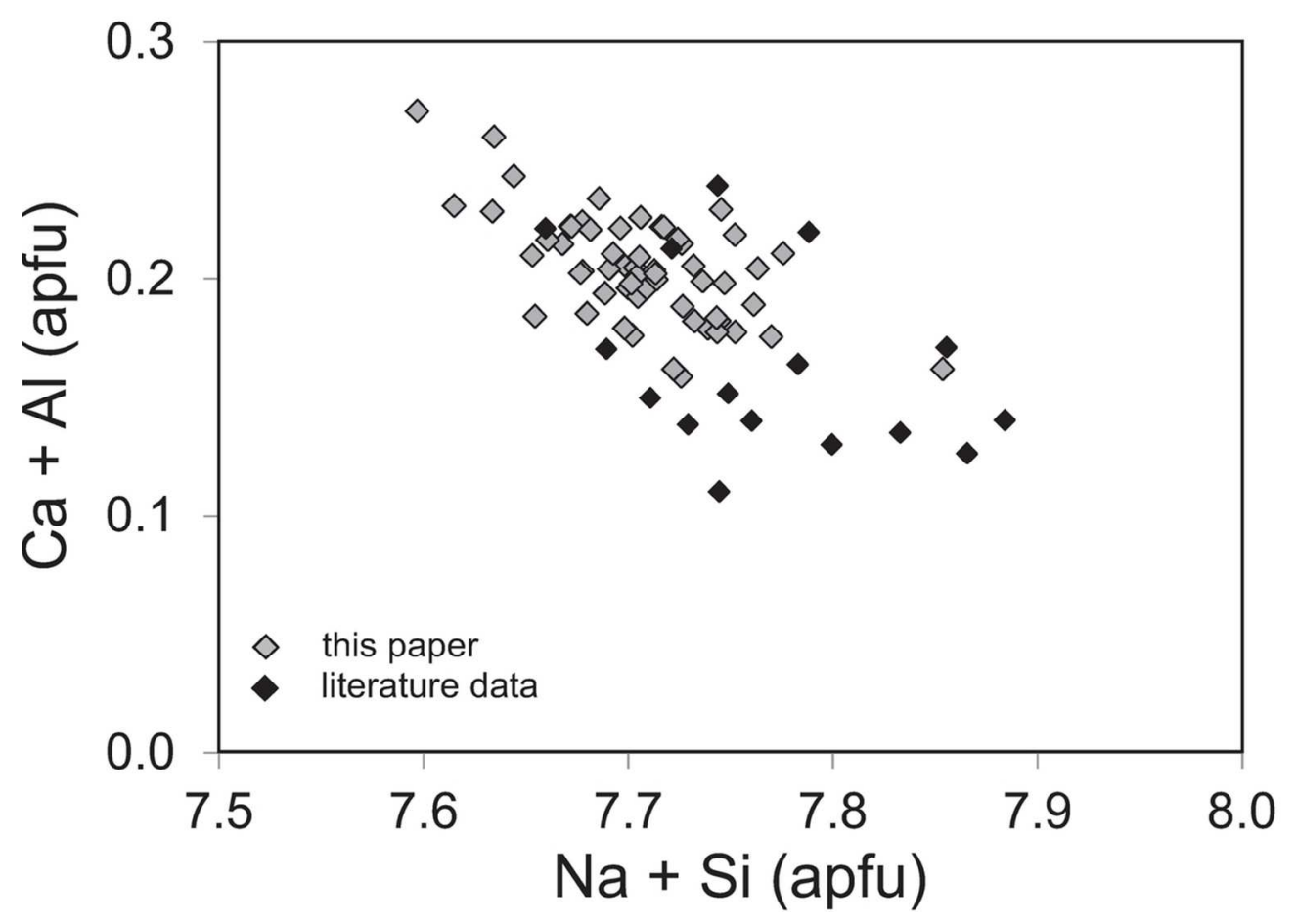

Figure 5. $(\mathrm{Si}+\mathrm{Na})$ plotted against $(\mathrm{Al}+\mathrm{Ca})$ for aenigmatite phenocrysts in the Green Tuff. New data from this paper, Electronic Appendix 2 (a); literature data from Mahood \& Stimac (1990), White et al. (2009) and Neave et al. (2012).

$107 \times 75 \mathrm{~mm}(300 \times 300 \mathrm{DPI})$ 

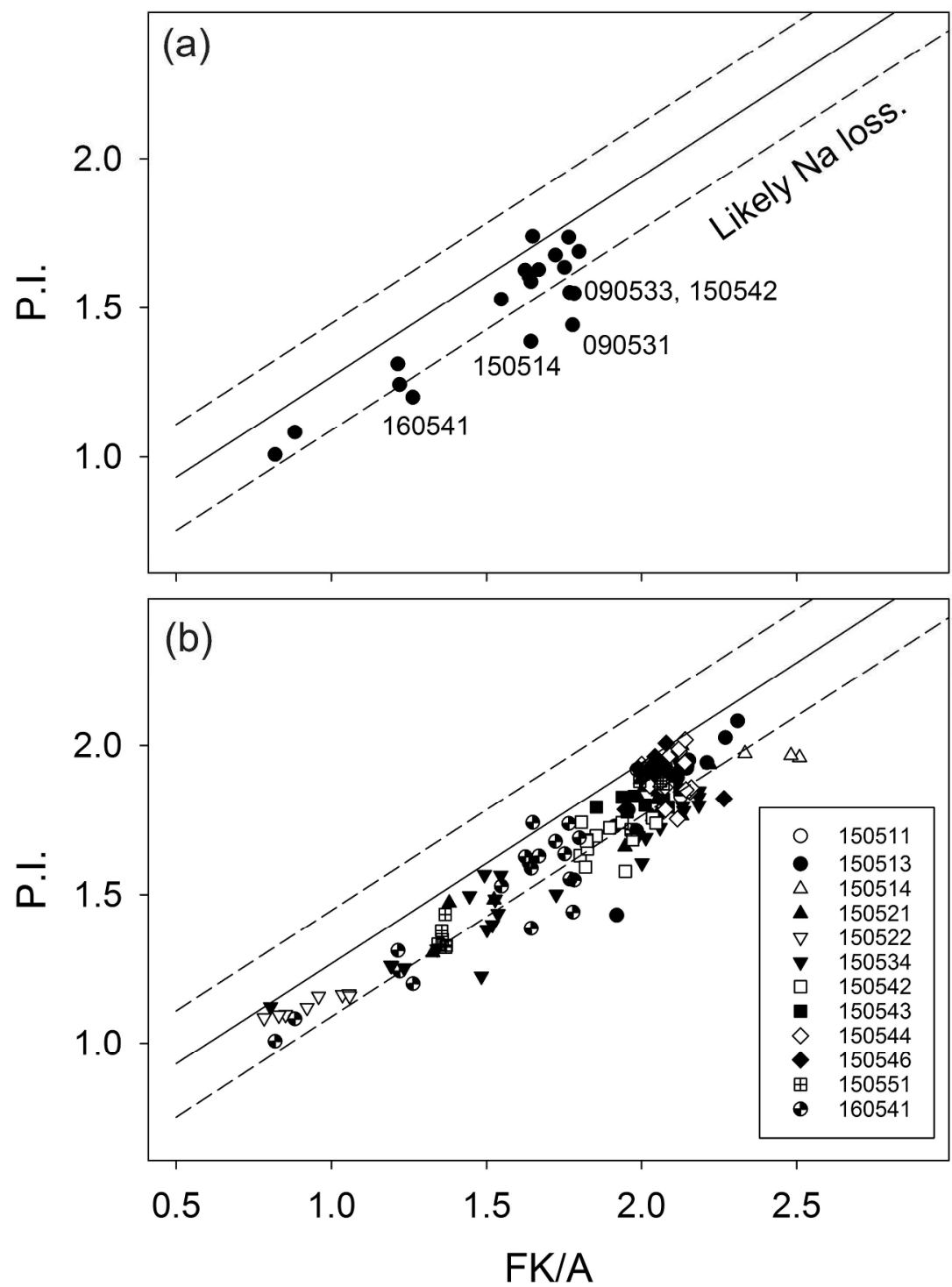

Figure 6. Plots of the FK/A index $\left(\mathrm{mol}\left(\mathrm{FeO}^{*}+\mathrm{K} 2 \mathrm{O}\right) / \mathrm{Al} 2 \mathrm{O} 3\right)$ versus the peralkalinity index $(\mathrm{P} . \mathrm{I}$. $=\mathrm{mol}$ $(\mathrm{Na2O}+\mathrm{K} 2 \mathrm{O}) / \mathrm{Al} 2 \mathrm{O3})$ to test for potential sodium loss in peralkaline rocks (White et al., 2003). (a) Wholerock compositions, with potentially altered samples labelled. Data from Table 2. (b) Glass analyses in individual samples (listed). Data from Electronic Appendix 3.

$$
216 \times 289 \mathrm{~mm}(300 \times 300 \mathrm{DPI})
$$




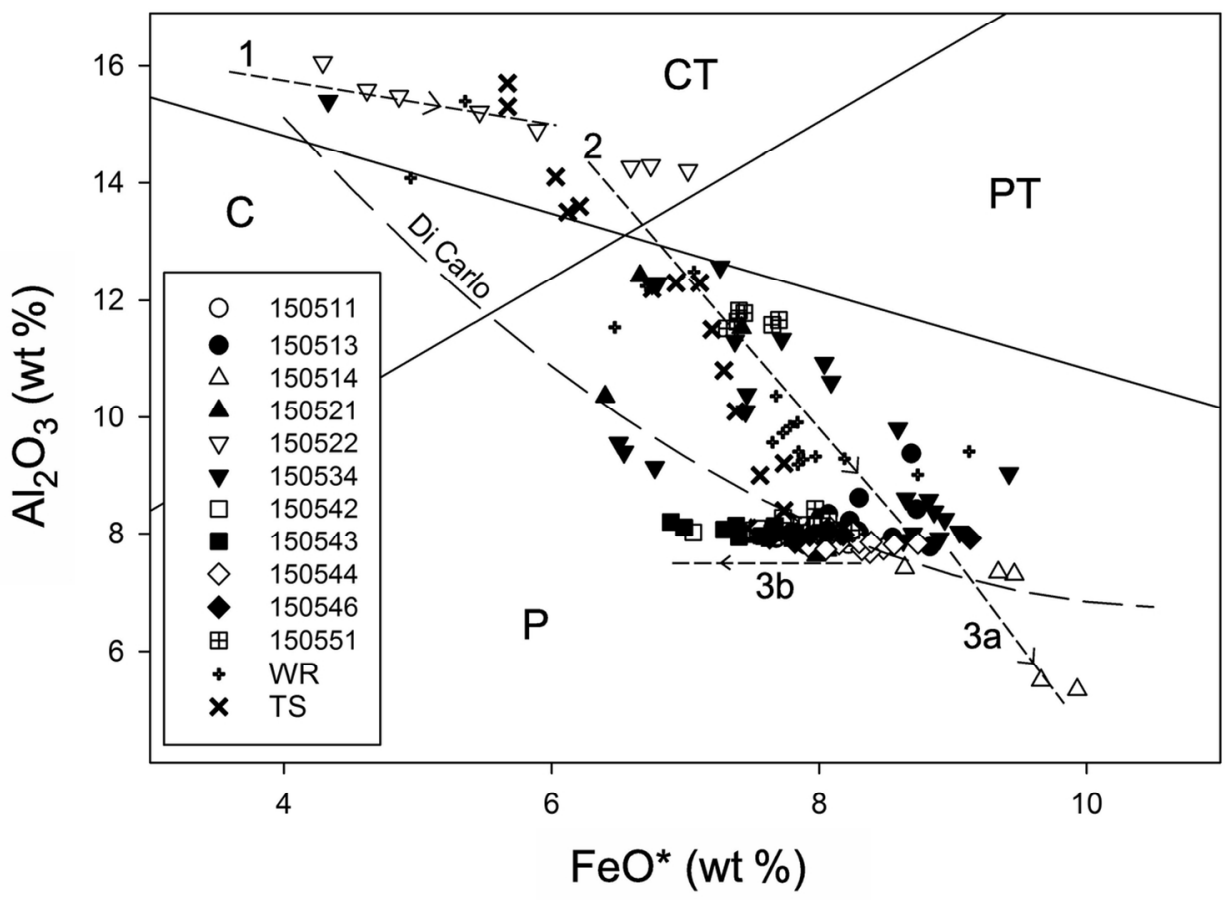

Figure 7. Whole-rocks (WR) and glass (all symbols except + and $x$ ) for Green Tuff plotted in the classification scheme for peralkaline silicic rocks of Macdonald (1974). CT, comenditic trachyte; C, comendite; PT, pantelleritic trachyte; P, pantellerite. TS - analyses for whole-rocks from the type section of the Green Tuff from Williams et al. (2014). Trends 1 to 3 reflect changing fractionating assemblages; see

text for details. The trend marked Di Carlo is for experimental glasses in the study of a Pantescan pantellerite by Di Carlo et al. (2010). Data sources: whole rocks (WR) - Table 2, this paper, Mahood \& Stimac (1990), White et al. (2009); glass - this paper, Electronic Appendix 3, Mahood \& Stimac (1990; samples 7, 226 and 231/233) and Neave et al. (2012; sample 09PNL033).

$121 \times 95 \mathrm{~mm}(300 \times 300 \mathrm{DPI})$ 

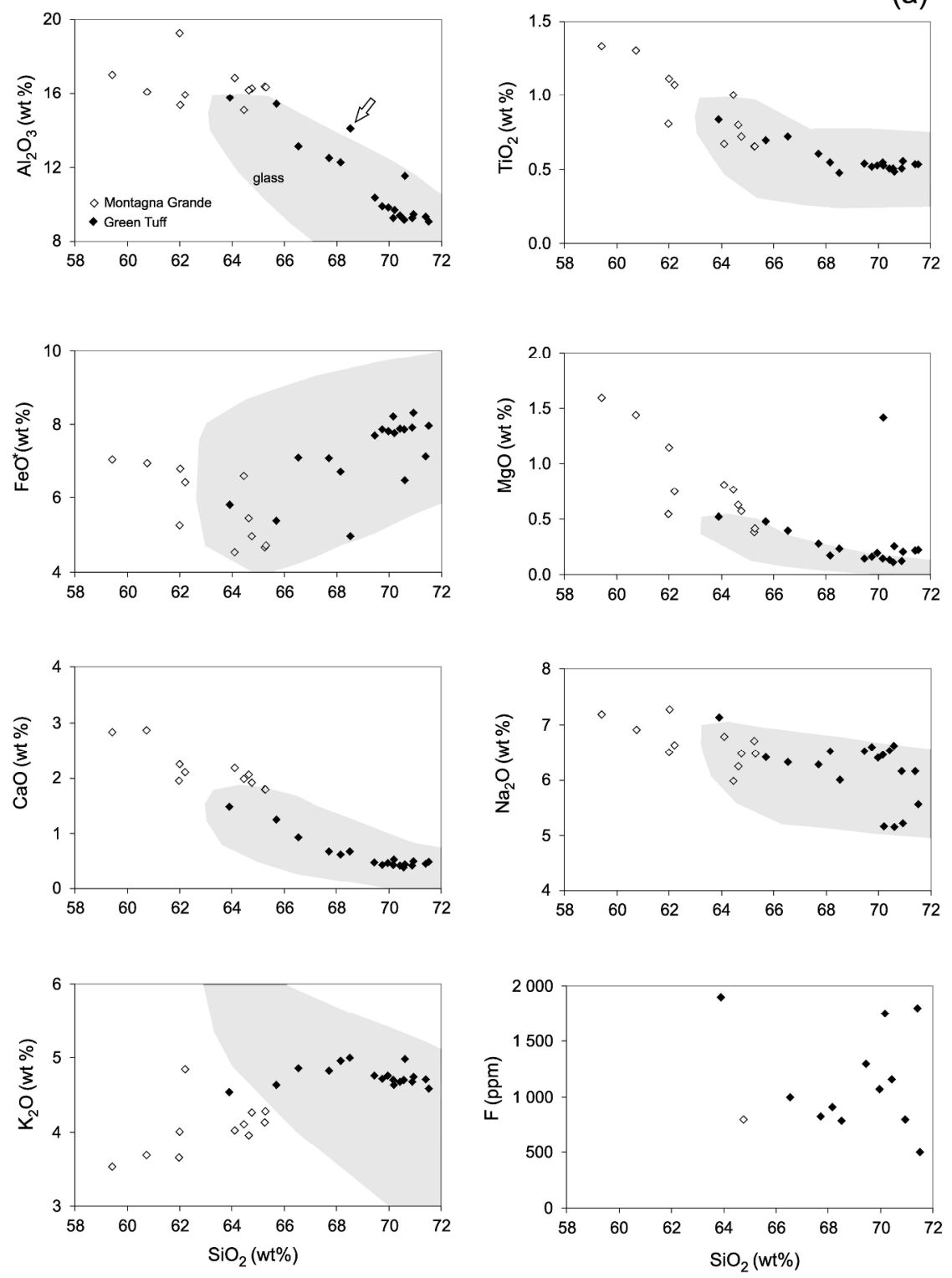

Figure 8. (a) Selected major element v. SiO2 plots for Green Tuff whole-rocks. The ranges of glass analyses are shown as fields. (b) Selected trace element v. SiO2 plots. Data from this paper, Table 2, Electronic Appendix 3, and White et al. (2009, samples 060537 and 060545). The arrowed sample (150541) in the Al2O3 and Ba plots is thought to be slightly feldspar-accumulitic. Also shown in both plots are whole-rock analyses of trachytes from Montagna Grande and Monte Gibele (data from Villari (1974), Mahood \& Hildreth (1986), Avanzinelli et al. (2004), Ferla \& Meli (2006) and White et al. (2009)). The field for MgO in glass has been drawn omitting two anomalously high analyses.

$$
276 \times 371 \mathrm{~mm}(300 \times 300 \mathrm{DPI})
$$


(b)
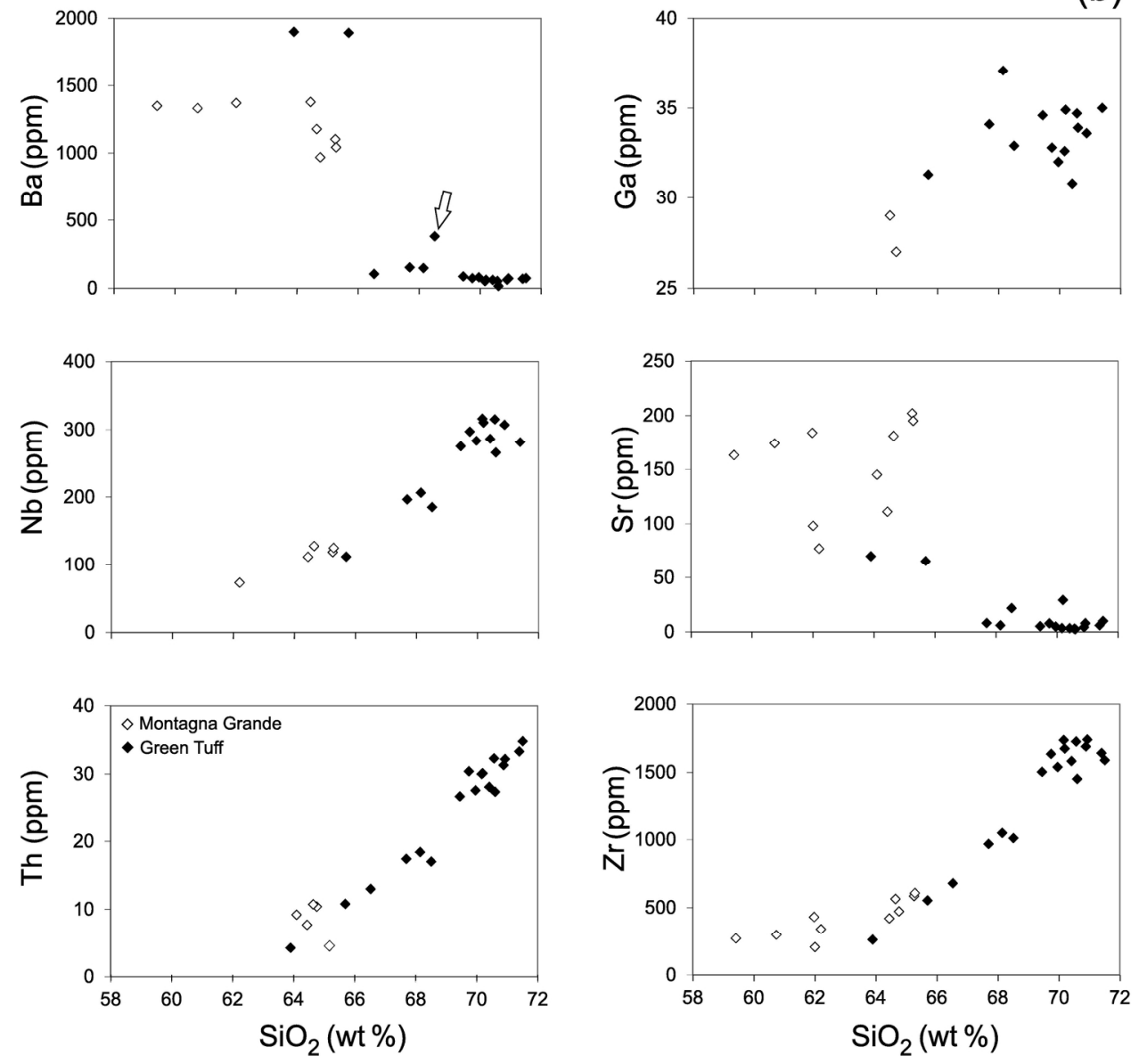

Figure 8. (a) Selected major element v. SiO2 plots for Green Tuff whole-rocks. The ranges of glass analyses are shown as fields. (b) Selected trace element v. SiO2 plots. Data from this paper, Table 2, Electronic Appendix 3, and White et al. (2009, samples 060537 and 060545). The arrowed sample (150541) in the Al2O3 and Ba plots is thought to be slightly feldspar-accumulitic. Also shown in both plots are whole-rock analyses of trachytes from Montagna Grande and Monte Gibele (data from Villari (1974), Mahood \& Hildreth (1986), Avanzinelli et al. (2004), Ferla \& Meli (2006) and White et al. (2009)). The field for MgO in glass has been drawn omitting two anomalously high analyses.

$178 \times 170 \mathrm{~mm}(300 \times 300 \mathrm{DPI})$ 

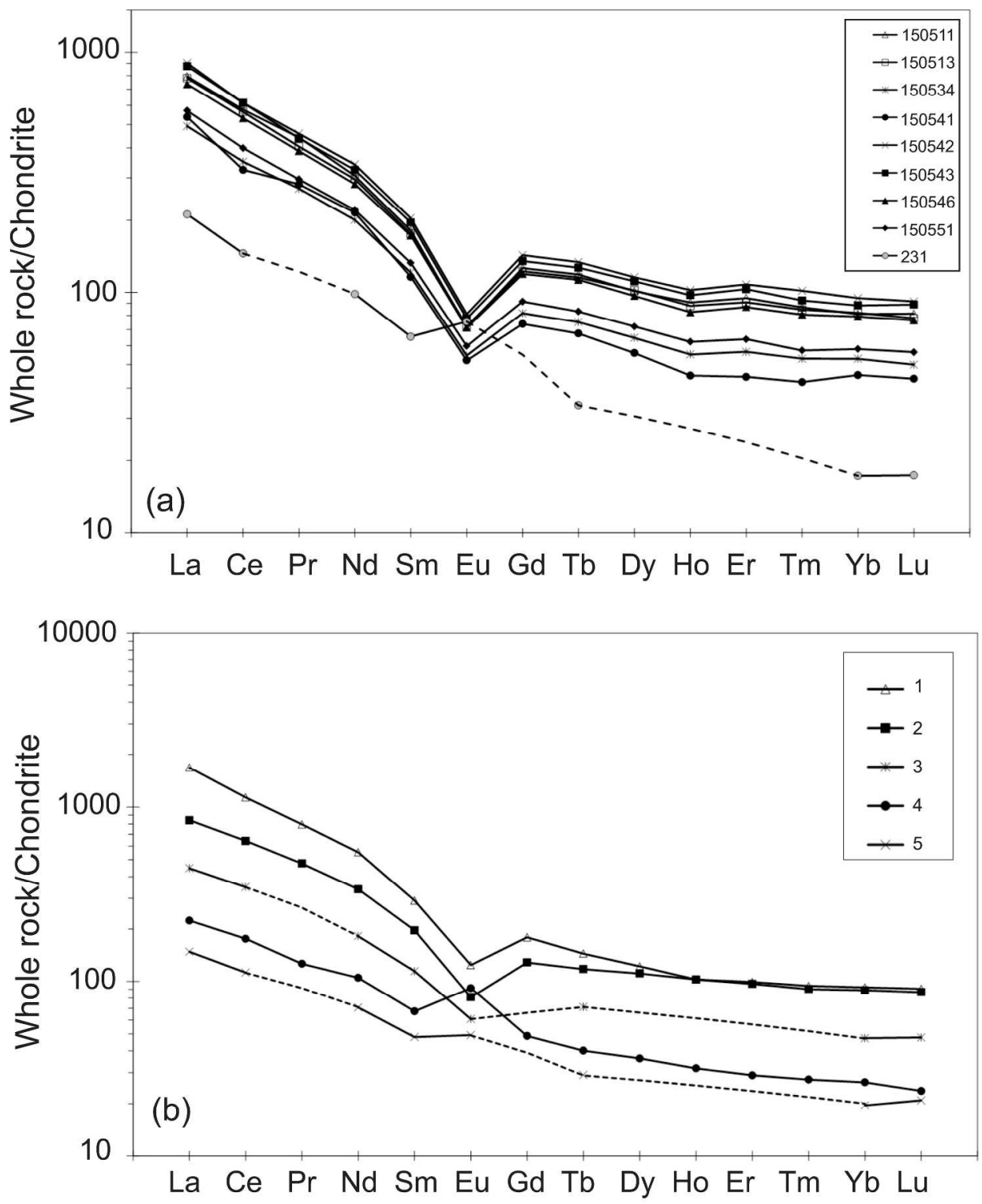

Figure 9. Chondrite-normalized REE plots for (a) whole-rocks and (b) glasses. Normalizing factors from Sun \& McDonough (1989). Data sources: whole-rocks, this paper, Table 2, and Mahood \& Stimac (1990, sample 231); glass, patterns 3 and 5, Mahood \& Stimac (1990; samples 226 and 231), pattern 2, Neave et al. (2012; sample 09PNL033) and patterns 1 and 4, Williams et al. (2014; samples 44E and 44H). Glass patterns 4 and 5 are comenditic trachyte, patterns 1, 2 and 3 are pantelleritic.

$238 \times 299 \mathrm{~mm}(300 \times 300 \mathrm{DPI})$ 

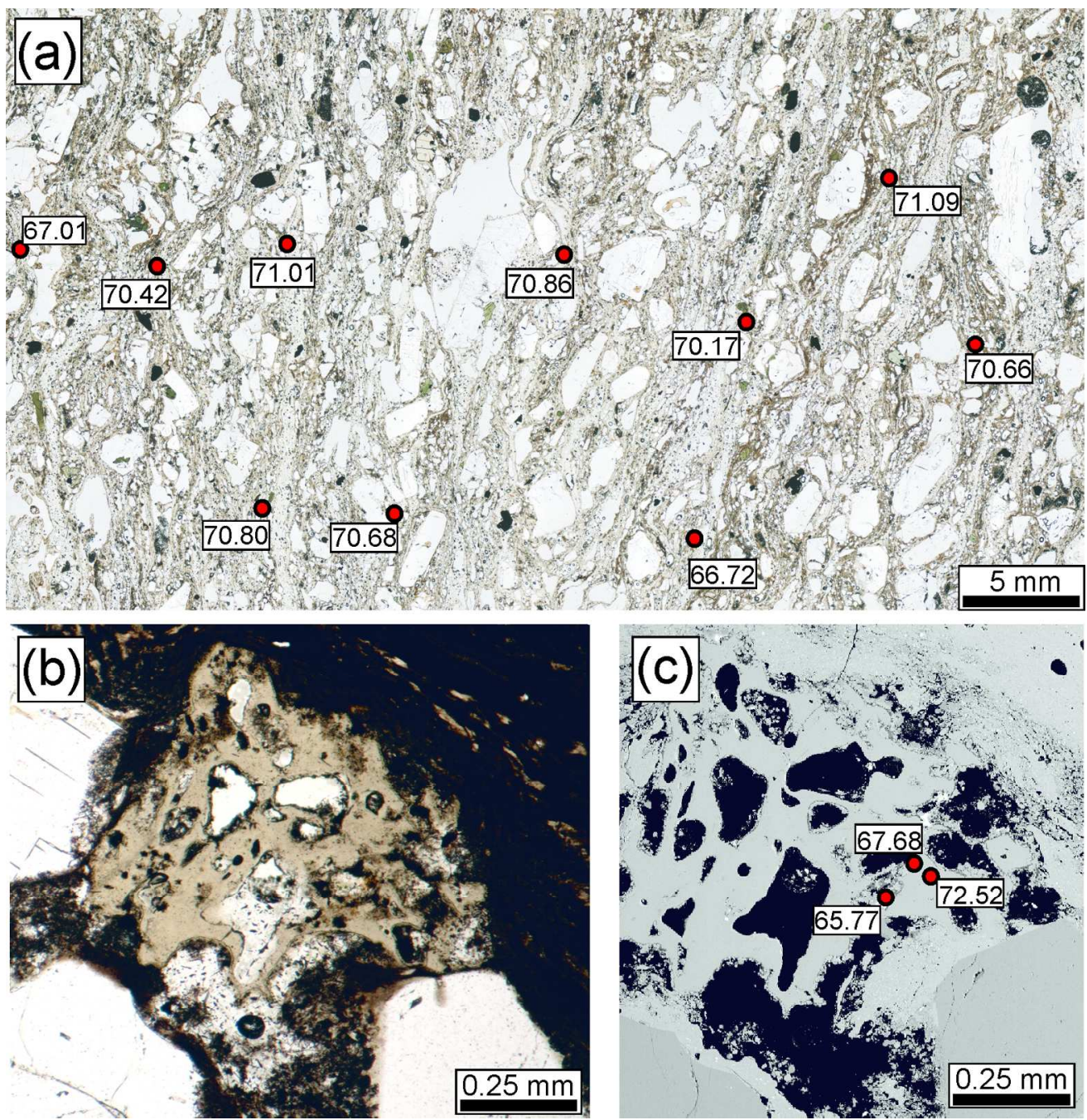

Figure 10. Examples of different styles of magma mixing in the Green Tuff. Values are for SiO2 wt \%. (a) Streaky intermingling of glass ranging in composition from 67 to 71 wt \% SiO2. Sample 150551. (b) Fragment of pale brown glass in very dark brown host. Sample 150521. (c) The composition of the pale glass in (b) ranges from 66 to 73 wt \% SiO2.

$157 \times 162 \mathrm{~mm}(300 \times 300 \mathrm{DPI})$ 

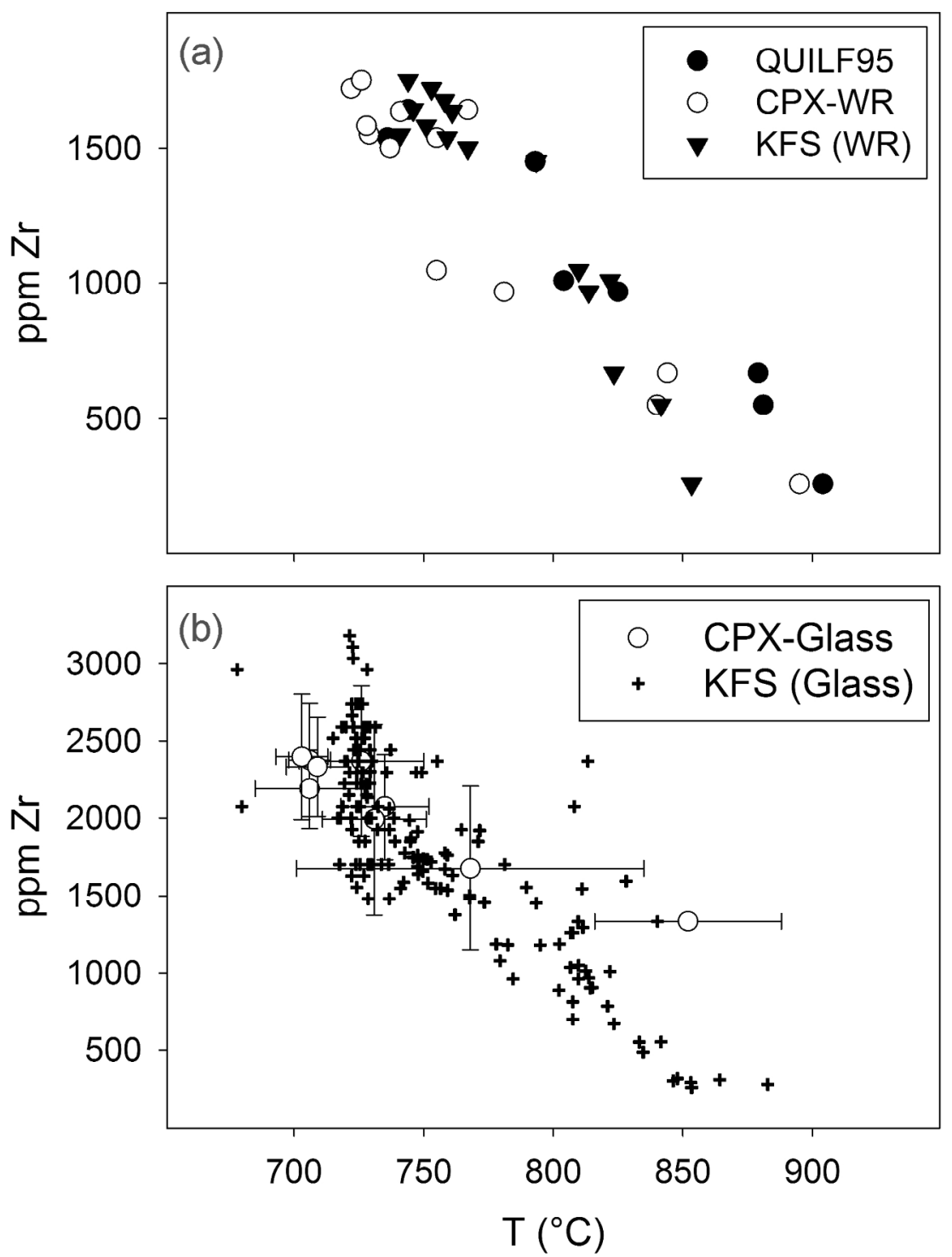

Figure 11. (a) Comparison of calculated temperatures $\left({ }^{\circ} \mathrm{C}\right)$ for whole-rock compositions and assemblages plotted against $\mathrm{Zr}$ concentration. QUILF95 points are calculated from olivine-clinopyroxene equilibria (Andersen et al., 1993). CPX-WR are calculated from clinopyroxene-whole rock compositions (Putirka et al., 2003). KFS were determined from the position of the whole rock composition in Fig. 12 (see text for details).

(b) Comparison of calculated temperatures for glass compositions plotted against Zr concentration, determined with the techniques described for (a). Averages with error bars are plotted for CPX and individual points are plotted for KFS to facilitate readability.

$$
167 \times 218 \mathrm{~mm} \text { ( } 300 \times 300 \text { DPI) }
$$


Figure 12. (a) Whole-rock and (b) glass analyses plotted in the system Q-Ab-Or-H2O with 8.3 mol\% aegirine +8.3 mol\% sodium metasilicate added and PH2O = 1000 bar. (Carmichael \& MacKenzie, 1963). Whole rock analyses displayed include those presented in this study (Table 2) and from the literature (Civetta et al., 1984, 1989; Kovalenko et al., 1994; Esperança \& Crisci, 1995; Avanzinelli et al., 2004; Ferla \& Meli, 2006; White et al., 2009; Williams et al., 2014). The crosses mark the alkali feldspar liquidus surface.

$153 \times 157 \mathrm{~mm}(300 \times 300 \mathrm{DPI})$ 

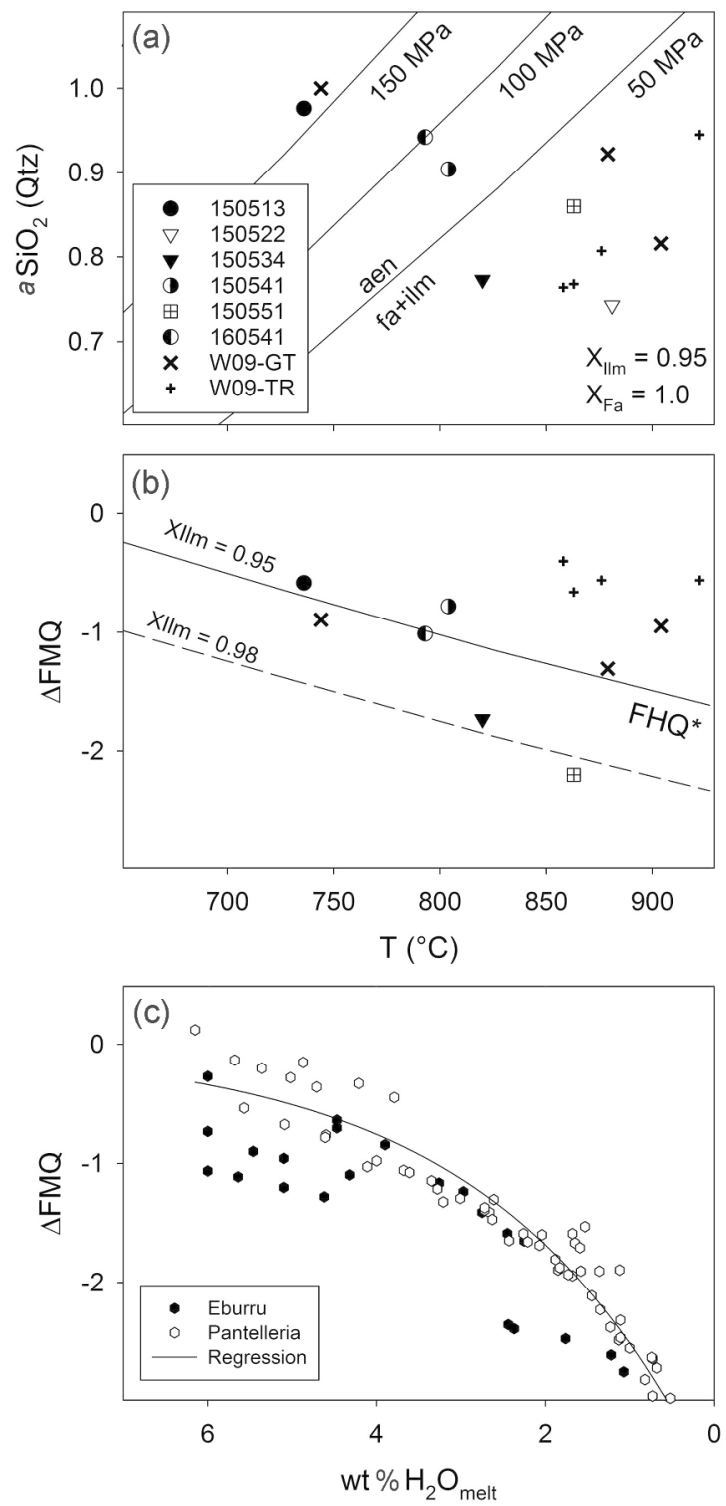

Figure 13. (a) Silica activity (aSiO2) relative to quartz saturation and (b) oxygen fugacity relative to the FMQ buffer plotted against temperature. W09-GT and W-O9-TR are the results of QUILF95 geothermobarometry for the Green Tuff and Montagna Grande Trachyte, respectively, from White et al. (2009). The fayaliteilmenite-aenigmatite stability curve for XIIm $=0.95$ is calculated following Macdonald et al. (2011), with ilmenite activities calculated with the solution model of Andersen \& Lindsley (1988). $\triangle F M Q=\log$ fO2 $\mathrm{FMQ}(\mathrm{T})$, with $\mathrm{FMQ}(\mathrm{T})$ calculated following Frost et al. (1988). (c) The experimental results of Scaillet \& Macdonald (2006) for Eburru and Di Carlo et al. (2010) for Pantelleria show the strong positive correlation between oxygen fugacity (as $\triangle \mathrm{FMQ}$ ) and melt water content (wt \% H2Omelt).

$127 \times 267 \mathrm{~mm}(300 \times 300$ DPI $)$ 
Figure 14. Eu/Eu* plotted against $\mathrm{Zr}$ content for Green Tuff samples. Data sources: whole-rocks - this paper, Table 2; Mahood \& Stimac (1990); White et al. (2009); glass - Mahood \& Stimac (1990, samples 7, 226, 231/233), Neave et al. (2012, sample 09PNL033), Williams et al. (2014, samples 44H and 44I).

$181 \times 122 \mathrm{~mm}(300 \times 300 \mathrm{DPI})$ 


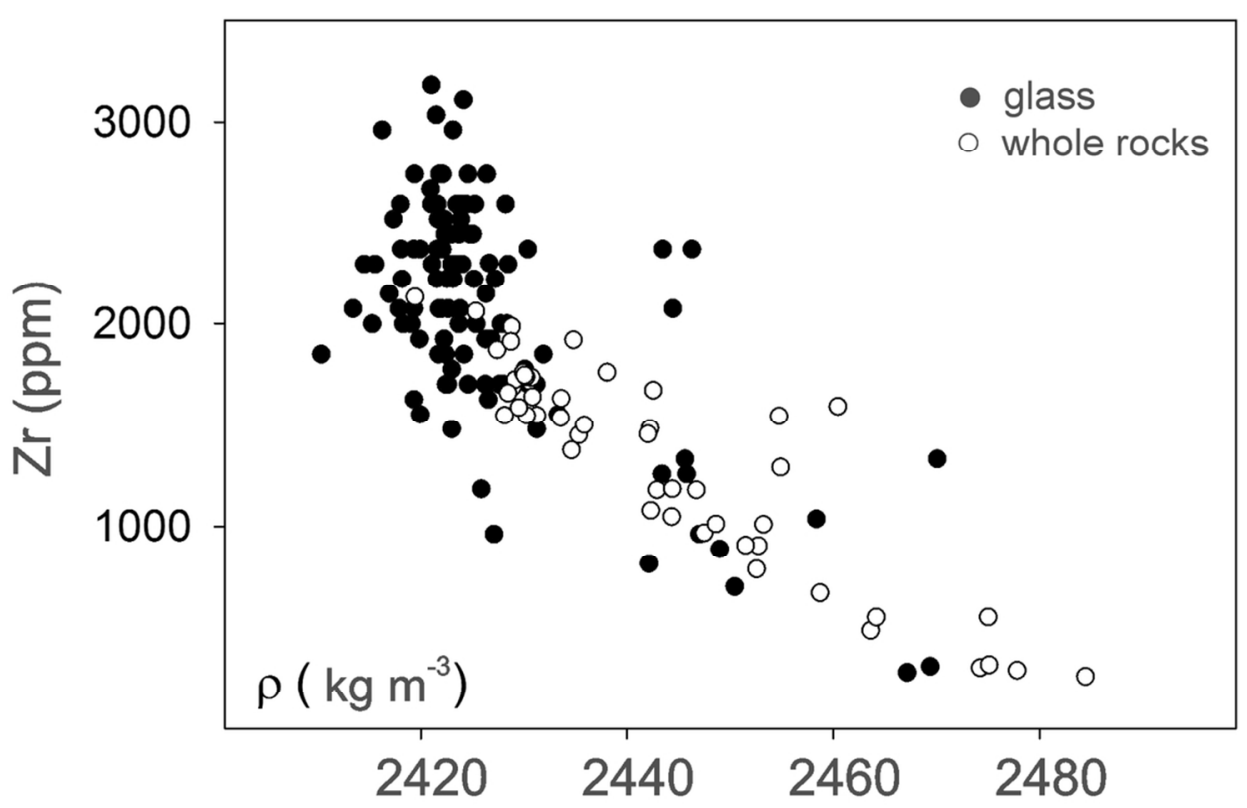

Figure 15. Anhydrous melt densities, calculated by the method of Bottinga \& Weill (1970), plotted against Zr contents for whole-rocks (open circles) and glasses (closed circles). The densities initially decrease to $\mathrm{Zr}$ $\sim 1500$ ppm and then change little with increasing Zr. Data sources: this paper, Table 2 and Electronic Appendix 3.

$101 \times 63 \mathrm{~mm}(300 \times 300 \mathrm{DPI})$ 
Figure 16. Maximum Zr content in glass in each Green Tuff whole-rock plotted against range of Zr contents in glass of same rock. The ranges indicate mixing in varying proportions of trachytic and rhyolitic melts. Also shown is the composition of a Montagna Grande glass, from Mahood \& Stimac (1990, sample 119); its relative compositional similarity to the Montagna Grande whole-rocks suggests that the range of glasses in each sample must be small. Montagna Grande whole-rock data from Mahood \& Stimac (1990), Avanzinelli et al. (2004), Ferla \& Meli (2006) and White et al. (2009).

$180 \times 113 \mathrm{~mm}(300 \times 300 \mathrm{DPI})$ 


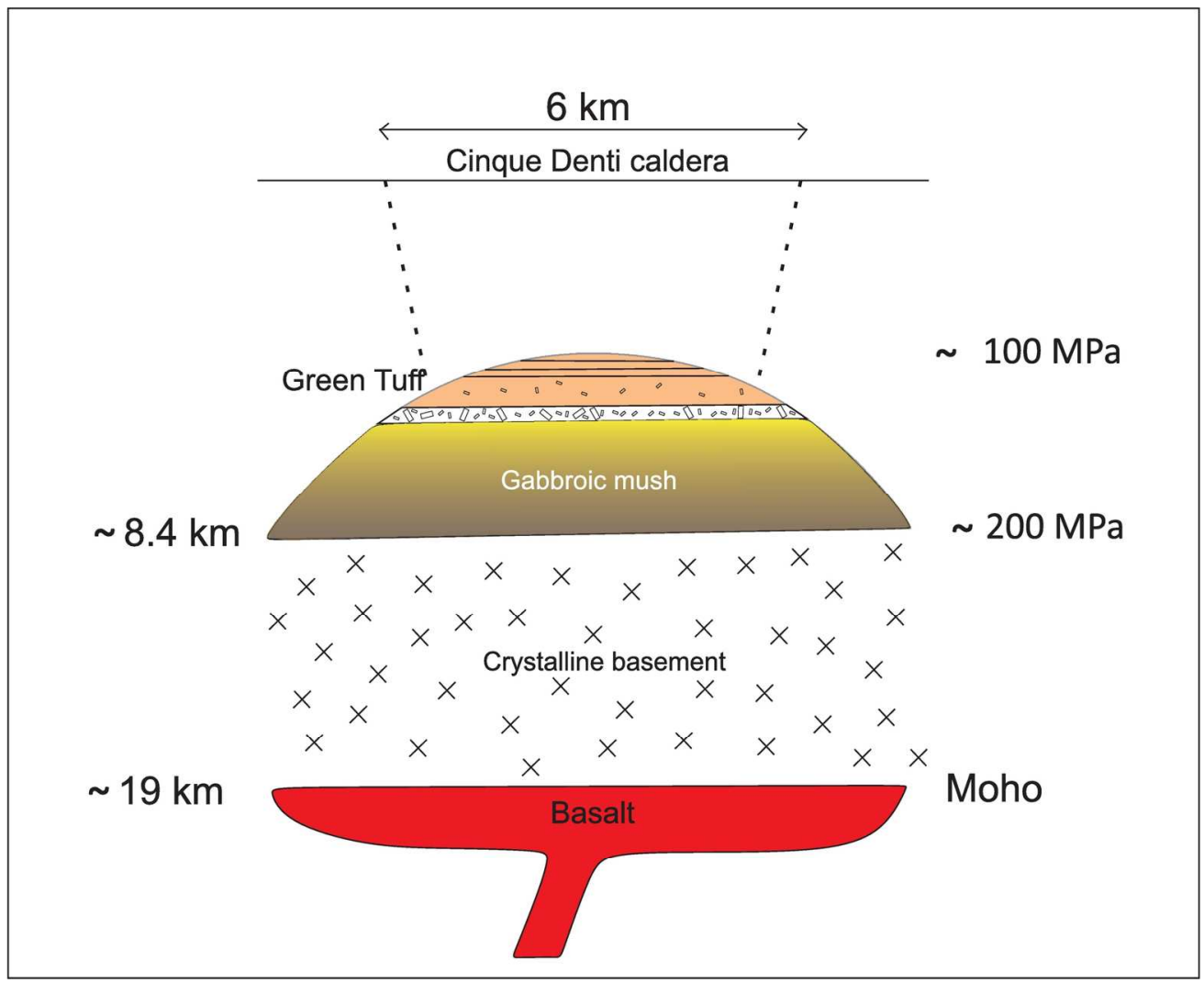

Figure 17. Possible relationships in the magmatic plumbing system prior to eruption of the Green Tuff. The crustal structure is from Civile et al. (1988).

$157 \times 128 \mathrm{~mm}(300 \times 300$ DPI $)$ 
1

2

3

4

5

6

7

8

9

10

11

12

13

14

15

16

17

18

19

20

21

22

23

24

25

26

27

28

29

30

31

32

33

34

35

36

37

38

39

40

41

42

43

44

45

46

47

48

49

50

51

52

53

54

55

56

57

58

59

60
Appendix. Details of analyzed samples

\begin{tabular}{cccccc}
\hline & & \multicolumn{2}{c}{ Geographic Coordinates } & \multicolumn{2}{c}{ UTM (Zone 32S) } \\
Sample ID & Rock type & Lat $\left({ }^{\circ} \mathrm{N}\right)$ & Long $\left({ }^{\circ} \mathrm{E}\right)$ & $\mathrm{mE}$ & $\mathrm{mN}$ \\
\hline 150511 & eutaxitic lapilli tuff & 36.76836 & 11.96072 & 764264 & 4073266 \\
150513 & rheomorphic tuff & 36.76811 & 11.95942 & 764147 & 4073234 \\
150514 & eutaxitic lapilli tuff & 36.77172 & 11.95600 & 763831 & 4073626 \\
150521 & glassy eutaxitic tuff & 36.77378 & 11.97467 & 765489 & 4073904 \\
150522 & top of deposit & 36.76689 & 11.98311 & 766269 & 4073164 \\
150534 & glassy top of section & 36.78792 & 11.94808 & 763069 & 4075401 \\
150541 & fall deposit (?) & 36.81133 & 11.97583 & 765465 & 4078078 \\
150542 & lower pumice & 36.81992 & 11.99858 & 767465 & 4079092 \\
150543 & fiamme bed & 36.81986 & 11.99817 & 767427 & 4079085 \\
150544 & basal bomb bed & 36.82425 & 11.98381 & 766133 & 4079530 \\
150546 & vitrophyric base & 36.82456 & 11.98522 & 766257 & 4079570 \\
150551 & glassy base of deposit & 36.83511 & 11.96942 & 764811 & 4080699 \\
160541 & densely welded tuff & 36.77375 & 11.97465 & 765489 & 4073902 \\
160542 & glassy upper unit & 36.77423 & 11.97454 & 765477 & 4073955 \\
160543 & eutaxitic lapilli tuff & 36.77479 & 11.97427 & 765451 & 4074017 \\
\hline
\end{tabular}

Datum for all coordinates is WGS84. 
Location

Punta Tre Pietre

Punta Tre Pietre

Punta Tre Pietre

Monastero Scarp

Monastero Scarp

Contrada Scirafi

Zinedi Scarp

Cinque Denti Scarp

Cinque Denti Scarp

Khartibucale Scarp

Khartibucale Scarp

Punta della Guarda

Monastero Scarp

Monastero Scarp

Monastero Scarp 
Table 1. Phenocryst and glass compositions

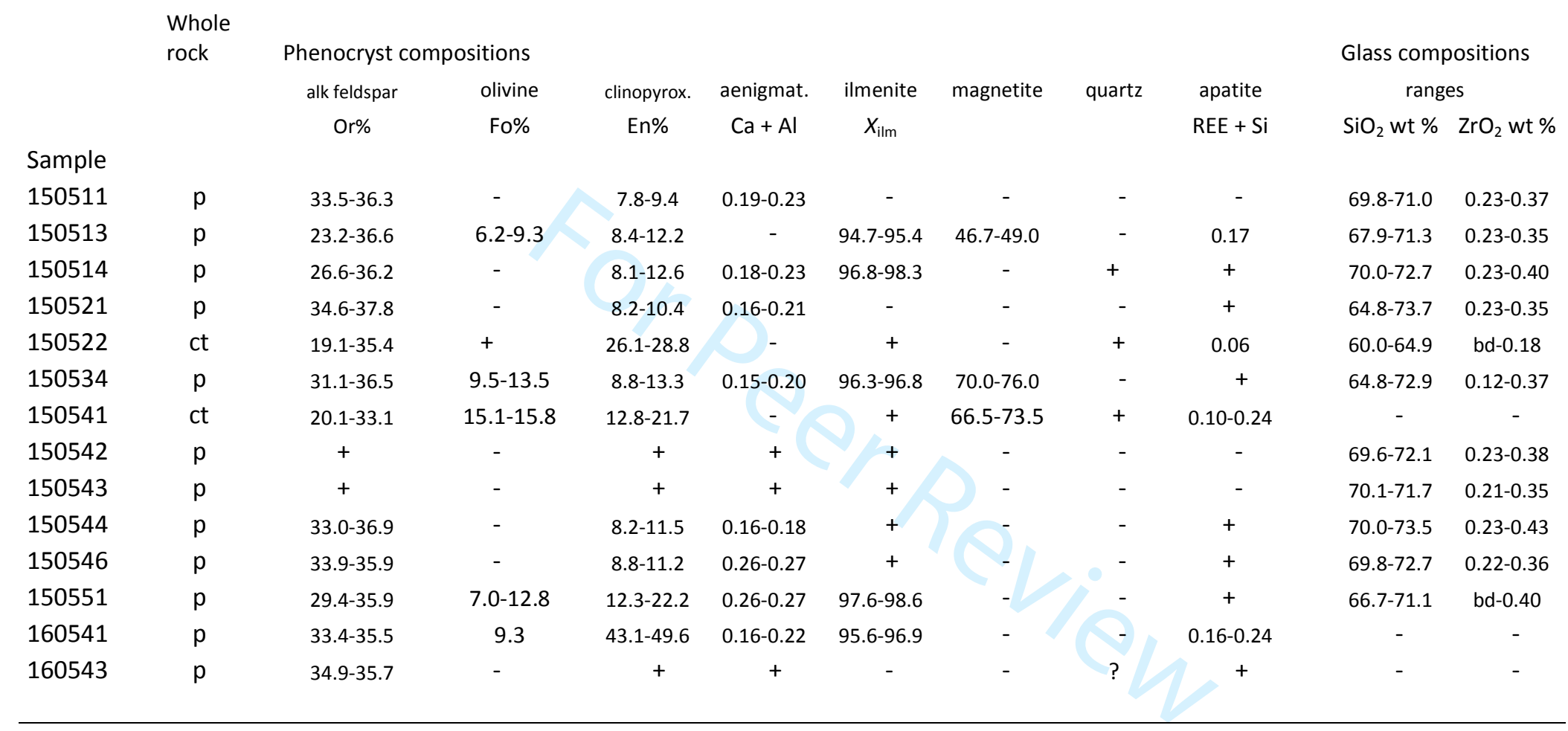

p, pantellerite; ct, comenditic trachyte (classification scheme of Macdonald (1974)); +, present but not analyzed. 


\begin{tabular}{|c|c|c|c|c|c|c|c|c|c|c|c|c|c|c|c|c|c|}
\hline Sample & 150511 & 150513 & 150514 & 150521 & 150522 & 150534 & 150541 & 150542 & 150543 & 150544 & 150546 & 150551 & 160541 & 160542 & 160543 & 090531 & 090533 \\
\hline Rock (L) & $\mathrm{R}$ & $\mathrm{T}$ & $T$ & $\mathrm{R}$ & $T$ & $T$ & T & T & $\mathrm{T}$ & $\mathrm{T}$ & $\mathrm{T}$ & $\mathrm{T}$ & $\mathrm{R}$ & $\mathrm{R}$ & $\mathrm{R}$ & $\mathrm{R}$ & $\mathrm{R}$ \\
\hline $\operatorname{Rock}(\mathrm{M})$ & & & $\mathrm{P}$ & & CT & & & & & & & $\mathrm{P}$ & & & $\mathrm{P}$ & $\mathrm{P}$ & $\mathrm{p}$ \\
\hline \multicolumn{18}{|l|}{$\overline{\mathrm{wt} \%}$} \\
\hline $\mathrm{SiO}_{2}$ & 69.22 & 68.78 & 67.51 & 69.07 & 64.68 & 65.59 & 67.34 & 67.55 & 68.84 & 67.99 & 68.07 & 67.02 & 69.51 & 69.33 & 69.37 & 70.16 & 69.19 \\
\hline $\mathrm{TiO}_{2}$ & 0.50 & 0.52 & 0.51 & 0.50 & 0.69 & 0.59 & 0.47 & 0.51 & 0.54 & 0.51 & 0.53 & 0.54 & 0.48 & 0.50 & 0.50 & 0.53 & 0.54 \\
\hline $\mathrm{Al}_{2} \mathrm{O}_{3}$ & 9.27 & 9.71 & 9.38 & 9.39 & 15.21 & 12.14 & 13.88 & 8.90 & 9.14 & 9.69 & 10.19 & 12.08 & 11.39 & 9.05 & 9.10 & 8.95 & 9.29 \\
\hline $\mathrm{FeO}^{*}$ & 7.74 & 7.68 & 7.46 & 7.51 & 5.29 & 6.87 & 4.88 & 7.61 & 8.06 & 7.67 & 7.55 & 6.61 & 6.39 & 7.73 & 7.74 & 8.68 & 9.01 \\
\hline $\mathrm{MnO}$ & 0.29 & 0.29 & 0.28 & 0.28 & 0.21 & 0.26 & 0.22 & 0.29 & 0.30 & 0.29 & 0.28 & 0.26 & 0.25 & 0.29 & 0.29 & 0.29 & 0.30 \\
\hline MgO & 0.13 & 0.19 & 1.36 & 0.12 & 0.47 & 0.27 & 0.23 & 0.21 & 0.14 & 0.16 & 0.14 & 0.17 & 0.25 & 0.11 & 0.12 & 0.22 & 0.20 \\
\hline $\mathrm{CaO}$ & 0.42 & 0.46 & 0.52 & 0.41 & 1.23 & 0.66 & 0.67 & 0.42 & 0.43 & 0.43 & 0.47 & 0.62 & 0.44 & 0.39 & 0.42 & 0.48 & 0.49 \\
\hline $\mathrm{Na}_{2} \mathrm{O}$ & 6.42 & 6.29 & 4.97 & 6.25 & 6.31 & 6.09 & 5.90 & 5.39 & 6.34 & 6.43 & 6.39 & 6.42 & 5.08 & 6.51 & 6.03 & 5.46 & 5.09 \\
\hline $\mathrm{K}_{2} \mathrm{O}$ & 4.60 & 4.68 & 4.46 & 4.62 & 4.57 & 4.68 & 4.92 & 4.56 & 4.62 & 4.60 & 4.67 & 4.88 & 4.91 & 4.62 & 4.58 & 4.50 & 4.63 \\
\hline $\mathrm{P}_{2} \mathrm{O}_{5}$ & 0.03 & 0.03 & 0.04 & 0.03 & 0.15 & 0.04 & 0.05 & 0.04 & 0.03 & 0.03 & 0.03 & 0.03 & 0.03 & 0.03 & 0.03 & 0.07 & 0.03 \\
\hline $\mathrm{F}$ & 0.12 & 0.11 & & & & 0.08 & 0.08 & 0.12 & 0.18 & & 0.13 & 0.09 & & & & 0.05 & 0.08 \\
\hline LOI & 0.10 & 0.10 & 2.20 & 0.50 & 0.20 & 1.80 & 0.60 & 3.20 & 0.20 & 0.90 & 0.40 & 0.30 & 0.20 & 0.10 & 0.50 & -0.10 & 0.04 \\
\hline Sum & 98.84 & 98.84 & 98.69 & 98.68 & 99.01 & 99.07 & 99.24 & 98.80 & 98.82 & 98.70 & 98.85 & 99.02 & 98.93 & 98.66 & 98.68 & 99.29 & 98.89 \\
\hline $\mathrm{O}=\mathrm{F}$ & 0.05 & 0.05 & & & & 0.03 & 0.03 & 0.05 & 0.08 & & 0.05 & 0.04 & & & & 0.02 & 0.03 \\
\hline Total & 98.79 & 98.79 & 98.69 & 98.68 & 99.01 & 99.03 & 99.20 & 98.75 & 98.75 & 98.70 & 98.79 & 98.99 & 98.93 & 98.66 & 98.68 & 99.27 & 98.86 \\
\hline Total C & 0.03 & 0.02 & 0.05 & 0.04 & 0.07 & 0.03 & 0.05 & 0.10 & 0.02 & 0.05 & 0.03 & 0.03 & 0.03 & 0.05 & 0.04 & & \\
\hline Total S & 0.03 & 0.04 & 0.04 & 0.03 & bd & 0.02 & $<0.02$ & $<0.02$ & 0.03 & 0.04 & 0.03 & 0.03 & bd & 0.03 & 0.03 & 0.01 & 0.01 \\
\hline \multicolumn{18}{|l|}{$\mathrm{ppm}$} \\
\hline $\mathrm{Ba}$ & 60 & 80 & 61 & 64 & 1893 & 153 & 380 & 61 & 52 & 73 & 86 & 148 & 16 & 52 & 62 & 74 & 71 \\
\hline Be & 4 & 11 & 10 & 13 & 2 & 3 & 4 & 18 & 9 & 8 & 11 & 5 & 6 & 8 & 8 & 12 & 9 \\
\hline co & 0.5 & 0.3 & 0.5 & 0.2 & 1.7 & 0.5 & 0.4 & 0.4 & 0.3 & 0.3 & 0.6 & 0.5 & 0.3 & 0.2 & 0.5 & $<0.1$ & $<0.1$ \\
\hline cs & 1.5 & 1.6 & 0.2 & 2 & 0.2 & 1.2 & 0.2 & 2.5 & 2.0 & 1.9 & 1.8 & 1.1 & 0.3 & 1.8 & 2.1 & 1.1 & $<0.2$ \\
\hline Ga & 30.8 & 32.0 & 34.9 & 33.2 & 31.3 & 34.1 & 32.9 & 30.8 & 32.6 & 32.8 & 34.6 & 37.1 & 33.9 & 34.7 & 33.6 & & \\
\hline $\mathrm{Hf}$ & 36.8 & 34.9 & 38.9 & 39.1 & 13 & 20.8 & 21.5 & 39.6 & 37.8 & 39 & 33.9 & 24.1 & 34.4 & 41.0 & 39.6 & 39.1 & 39.8 \\
\hline $\mathrm{Nb}$ & 286 & 283.1 & 310.3 & 314.2 & 112.1 & 196.3 & 185 & 313.1 & 315.9 & 296.8 & 274.8 & 206.2 & 265.5 & 315.1 & 306.9 & & \\
\hline $\mathrm{Rb}$ & 151.1 & 143.9 & 114.1 & 170.7 & 66 & 100.6 & 93.6 & 160.1 & 160.8 & 157.9 & 142.1 & 110.8 & 145.8 & 170.7 & 166.0 & 180 & 160 \\
\hline Sc & 3 & 3 & 3 & 4 & 10 & 6 & 4 & 3 & 3 & 3 & 4 & 5 & 6 & 3 & 3 & 4.1 & 4.4 \\
\hline Sn & 24 & 12 & 16 & 12 & 8 & 19 & 7 & 12 & 16 & 13 & 12 & 15 & 8.0 & 12.0 & 12 & & \\
\hline $\mathrm{Sr}$ & 3.3 & 4.7 & 29.2 & 4.3 & 65.4 & 8.1 & 21.7 & 8.3 & 3.3 & 7.7 & 5.1 & 6.0 & 2.4 & 2.8 & 4.3 & 10 & 8 \\
\hline Ta & 17.0 & 16.5 & 18.3 & 18.3 & 6.5 & $\begin{array}{l}0.1 \\
11.4\end{array}$ & 10.5 & 19.0 & 18.5 & 19.5 & $\begin{array}{l}16.7 \\
16.7\end{array}$ & 12.2 & $\begin{array}{l}2.7 \\
17.3\end{array}$ & 19.9 & 18.8 & 20.4 & 21.8 \\
\hline Th & 28.1 & 27.6 & 30.1 & 31.5 & 10.8 & 17.4 & 17.0 & 31.5 & 30.0 & 30.4 & 26.7 & 18.4 & 27.4 & 32.3 & 31.3 & 34.8 & 32.2 \\
\hline u & 8.7 & 8.8 & 3.1 & 9.8 & 1.3 & 4.7 & 1.4 & 9.6 & 9.3 & 9.4 & 7.8 & 5.4 & 5.2 & $\begin{array}{l}10.2 \\
10.2\end{array}$ & 9.3 & $\begin{array}{l}5.0 \\
7.7\end{array}$ & 4.5 \\
\hline w & 4.1 & 4.5 & 1.6 & 4.5 & 1.3 & 2.6 & 1.4 & 4.7 & 4.5 & 4 & 3.8 & 2.8 & 1.1 & 5.0 & 4.9 & $<1$ & 8 \\
\hline $\mathrm{Zr}$ & 1582.2 & 1537.9 & 1673.8 & 1718.1 & 552.5 & 967.5 & 1010 & 1760.6 & 1736.3 & 1633.7 & 1502.9 & 1047.7 & 1451.3 & 1725.2 & 1689.9 & 1589.0 & 1740.0 \\
\hline Y & 141.6 & 136.0 & 144.3 & 147.1 & 50.5 & 85.0 & 64.7 & 161.7 & 146.5 & 136.3 & 130.3 & 94.0 & 53.1 & 146.9 & 140.0 & 129.0 & 100.0 \\
\hline La & 188.1 & 184.7 & 207.8 & 203.2 & 84 & 116.6 & 127.3 & 213.8 & 207.3 & 191.8 & 174.5 & 135.1 & 146.6 & 212.2 & 204.7 & 206.0 & 202.0 \\
\hline $\mathrm{Ce}$ & 352.2 & 344.9 & 377.6 & 383.3 & 152.4 & 214.5 & 198.5 & 376.0 & 375.8 & 373.2 & 324.9 & 244.1 & 269.7 & 394.8 & 394.9 & 309.0 & 318.0 \\
\hline $\mathrm{Pr}$ & 41.91 & 38.45 & 40.76 & 41.57 & 17.97 & 25.73 & 26.81 & 43.46 & 41.62 & 39.43 & 36.85 & 28.12 & 26.94 & 42.05 & 41.32 & & \\
\hline $\mathrm{Nd}$ & 143.0 & 138.5 & 145.8 & 147.4 & 67.3 & 93.7 & 100.6 & 159.4 & 151.1 & 138.7 & 132.1 & 103.2 & 92.2 & 153.7 & 146.2 & 135.0 & 138.0 \\
\hline Sm & 27.72 & 26.86 & 28.48 & 28.76 & 12.68 & 18.52 & 17.76 & 31.22 & 29.93 & 27.11 & 26.38 & 20.31 & 14.94 & 29.24 & $\begin{array}{l}18.6 \\
28.63\end{array}$ & 23.90 & 23.60 \\
\hline Eu & 4.14 & 4.20 & 4.46 & 4.41 & 4.38 & 3.16 & 3.02 & 4.71 & 4.51 & 4.1 & 4.13 & 3.46 & 1.82 & 4.45 & 4.33 & 4.34 & 4.35 \\
\hline $\mathrm{Gd}$ & 25.96 & 25.17 & 26.42 & 26.55 & 11.74 & 16.81 & 15.17 & 29.4 & 27.76 & 24.94 & 24.54 & 18.82 & 11.65 & 26.92 & 25.87 & & \\
\hline $\mathrm{Tb}$ & 4.44 & 4.32 & 4.42 & 4.40 & 1.83 & 2.81 & 2.52 & 5.00 & 4.74 & $\begin{array}{l}2.34 \\
4.21\end{array}$ & $\begin{array}{l}2.22 \\
4.22\end{array}$ & 3.11 & 1.81 & 4.52 & 4.40 & 3.30 & 3.40 \\
\hline Dy & 25.72 & 25.91 & 26.36 & 27.04 & 10.29 & 16.42 & 14.19 & 29.41 & 28.27 & 25.73 & 24.57 & 18.28 & 10.70 & 26.99 & 26.89 & & \\
\hline Ho & 5.14 & 4.97 & 5.46 & 5.64 & 2.03 & 3.12 & 2.55 & 5.79 & 5.51 & 5.21 & 4.68 & 3.52 & 2.03 & 5.60 & 5.39 & & \\
\hline $\mathrm{Er}$ & 15.65 & 15.03 & 15.25 & 15.92 & 5.31 & 9.34 & 7.36 & 17.84 & 17.05 & 15.08 & 14.36 & 10.54 & 6.46 & 15.99 & 15.61 & & \\
\hline $\mathrm{Tm}$ & 2.21 & 2.16 & 2.28 & 2.28 & 0.78 & 1.35 & 1.08 & 2.59 & 2.36 & 2.18 & 2.06 & 1.46 & 1.02 & 2.27 & 2.28 & & \\
\hline $\mathrm{Yb}$ & 13.80 & 13.97 & 14.57 & 14.29 & 4.92 & 8.99 & 7.70 & 16.08 & 15.00 & 13.70 & 13.46 & 9.87 & 7.38 & 14.93 & 14.55 & 13.30 & 12.00 \\
\hline Lu & 2.07 & 1.98 & 2.10 & 2.10 & 0.68 & 1.27 & 1.11 & 2.33 & 2.26 & 2.01 & 1.94 & 1.43 & 1.18 & 2.18 & 2.09 & 1.95 & 1.78 \\
\hline Peralk Ix & 1.68 & 1.59 & 1.3 & 1.63 & 1.01 & 1.24 & 1.08 & 1.55 & 1.69 & 1.61 & 1.53 & 1.31 & 1.20 & 1.74 & 1.63 & 1.55 & 1.44 \\
\hline $\mathrm{Eu} / \mathrm{Eu}^{*}$ & 0.45 & 0.47 & 0.48 & 0.47 & 1.08 & 0.53 & 0.54 & 0.46 & 0.46 & 0.47 & 0.47 & 0.52 & 0.41 & 0.47 & 0.47 & 0.56 & 0.57 \\
\hline$[\mathrm{La} / \mathrm{Vb}]$ & 9.78 & 9.48 & 10.23 & 10.20 & 12.25 & 9.30 & 11.86 & 9.54 & 9.91 & 10.04 & 9.30 & 9.82 & 14.25 & 10.19 & 10.09 & 10.44 & 11.35 \\
\hline$[\mathrm{Tb} / \mathrm{Yb}]$ & 1.46 & 1.41 & 1.38 & 1.40 & 1.69 & 1.42 & 1.49 & 1.41 & 1.44 & 1.40 & 1.43 & 1.43 & 1.11 & 1.38 & 1.37 & 1.09 & 1.25 \\
\hline
\end{tabular}


Table 3. Representative compositions of matrix glasses and melt inclusions in Green Tuff

\begin{tabular}{|c|c|c|c|c|c|c|c|c|c|c|c|c|}
\hline & 1 & 2 & 3 & 4 & 5 & 6 & 7 & 8 & 9 & 10 & 11 & 12 \\
\hline \multicolumn{13}{|l|}{$\overline{w t \%}$} \\
\hline $\mathrm{SiO}_{2}$ & 69.96 & 62.84 & 63.04 & 64.79 & 71.49 & 67.27 & 71.90 & 70.98 & 66.72 & 70.68 & 72.52 & 72.74 \\
\hline $\mathrm{TiO}_{2}$ & 0.46 & 1.07 & 0.72 & 0.40 & 0.48 & 0.47 & 0.42 & 0.49 & 0.69 & 0.52 & 0.73 & 0.72 \\
\hline $\mathrm{ZrO}_{2}$ & 0.27 & bd & bd & bd & bd & 0.12 & 0.33 & 0.43 & 0.11 & 0.25 & 0.40 & 0.28 \\
\hline $\mathrm{Al}_{2} \mathrm{O}_{3}$ & 7.86 & 14.10 & 14.64 & 15.16 & 9.72 & 11.15 & 8.05 & 7.63 & 11.68 & 7.87 & 5.31 & 5.45 \\
\hline $\mathrm{FeO} *$ & 8.30 & 7.02 & 5.89 & 4.33 & 5.39 & 7.37 & 7.75 & 8.05 & 7.40 & 7.65 & 9.93 & 9.66 \\
\hline $\mathrm{MnO}$ & 0.32 & 0.19 & 0.17 & 0.14 & 0.15 & 0.15 & 0.42 & 0.31 & 0.27 & 0.31 & 0.45 & 0.31 \\
\hline $\mathrm{MgO}$ & 0.09 & 0.44 & 0.35 & 0.72 & 0.72 & 0.23 & 0.12 & 0.09 & 0.16 & 0.11 & 0.13 & 0.15 \\
\hline $\mathrm{CaO}$ & 0.34 & 1.74 & 1.24 & 0.68 & 0.80 & 1.63 & 0.27 & 0.26 & 0.42 & 0.37 & 0.46 & 0.36 \\
\hline $\mathrm{Na}_{2} \mathrm{O}$ & 6.26 & 7.00 & 6.86 & 6.68 & 6.06 & 6.20 & 5.84 & 6.38 & 6.55 & 6.11 & 5.60 & 5.64 \\
\hline $\mathrm{K}_{2} \mathrm{O}$ & 4.58 & 4.56 & 5.24 & 5.58 & 3.14 & 4.14 & 3.41 & 4.53 & 4.92 & 4.55 & 4.29 & 4.27 \\
\hline $\mathrm{P}_{2} \mathrm{O}_{5}$ & bd & 0.26 & 0.11 & bd & $\mathrm{bd}$ & bd & bd & bd & bd & bd & bd & bd \\
\hline $\mathrm{Cl}$ & 0.93 & 0.07 & $b d$ & 0.07 & 0.07 & 0.34 & 1.16 & 0.99 & 0.52 & 0.86 & 1.05 & 0.99 \\
\hline $\mathrm{SO}_{3}$ & 0.06 & 0.07 & 0.08 & 0.04 & 0.06 & 0.07 & 0.07 & 0.10 & 0.09 & 0.08 & 0.16 & 0.11 \\
\hline Sum & 99.43 & 99.36 & 98.34 & 98.59 & 98.08 & 99.14 & 99.74 & 100.24 & 99.53 & 99.36 & 101.44 & 101.43 \\
\hline $\mathrm{O}=\mathrm{Cl}$ & 0.21 & 0.02 & 0.00 & 0.02 & 0.02 & 0.08 & 0.27 & 0.23 & 0.12 & 0.20 & 0.24 & 0.23 \\
\hline Sum & 99.22 & 99.34 & 98.34 & 98.57 & 98.06 & 99.06 & 99.47 & 100.01 & 99.41 & 99.16 & 101.20 & 101.20 \\
\hline P.I. & 1.94 & 1.17 & 1.16 & 1.12 & 1.38 & 1.32 & 1.65 & 2.02 & 1.38 & 1.90 & 2.61 & 2.55 \\
\hline
\end{tabular}

Explanation: 1, pale brown glass, sample 150511; 2, dark bleb, 150522; 3, melt inclusion in feldspar, 150522; 4, 5, black blebs of glass, 150534;

6, pale glass, 150534; 7, brown glass, 150542; 8, grey speckled glass, 150544; 9, 10, brown glass, 150551; 11, 12, melt inclusions in feldspar, 150514. $\mathrm{FeO}$, all Fe as $\mathrm{Fe}^{2+}$. bd, below detection. P.I., peralkalinity index $\left(\mathrm{mol} .\left(\mathrm{Na}_{2} \mathrm{O}+\mathrm{K}_{2} \mathrm{O}\right) / \mathrm{Al}_{2} \mathrm{O}_{3}\right)$. 
Table 4. Results of major-element mass balance modelling.

\begin{tabular}{|c|c|c|c|c|c|c|c|c|c|c|c|c|}
\hline \multirow{2}{*}{\multicolumn{2}{|c|}{$\begin{array}{r}\text { Parent } \\
\text { (A) Comenditic Trach }\end{array}$}} & Daughter & \multicolumn{5}{|c|}{ Mineral Phases } & \multirow[t]{3}{*}{ Calc } & \multirow[t]{3}{*}{$\mathbf{r}$} & \multicolumn{3}{|c|}{ Results } \\
\hline & & te Glass to & antellerit & lass & & & & & & & & \\
\hline & 150522 & 150514 & Anr & Aug & OI & $\| \mathrm{m}$ & Ap & & & & & \\
\hline $\mathrm{SiO}_{2}$ & 65.07 & 71.38 & 67.45 & 49.07 & 30.37 & 0.00 & 0.00 & 65.08 & -0.01 & 150514 & 0.07 & $=\mathrm{F}$ \\
\hline $\mathrm{TiO}_{2}$ & 0.71 & 0.36 & 0.00 & 0.21 & 0.00 & 52.08 & 0.00 & 0.72 & -0.01 & Anr & 0.86 & $92.5 \%$ \\
\hline $\mathrm{Al}_{2} \mathrm{O}_{3}$ & 16.05 & 7.34 & 18.17 & 0.44 & 0.00 & 0.00 & 0.00 & 16.10 & -0.04 & Aug & 0.03 & $2.8 \%$ \\
\hline $\mathrm{FeO}^{*}$ & 4.30 & 9.49 & 0.76 & 25.20 & 60.08 & 45.73 & 0.57 & 4.29 & 0.01 & Ol & 0.03 & $3.0 \%$ \\
\hline $\mathrm{MnO}$ & 0.17 & 0.82 & 0.00 & 1.46 & 4.03 & 1.99 & 0.20 & 0.24 & -0.07 & $\mathrm{IIm}$ & 0.01 & $1.4 \%$ \\
\hline $\mathrm{MgO}$ & 0.21 & 0.13 & 0.00 & 3.88 & 4.93 & 0.20 & 0.06 & 0.25 & -0.04 & $\mathrm{Ap}$ & 0.00 & $0.3 \%$ \\
\hline $\mathrm{CaO}$ & 0.76 & 0.20 & 0.07 & 18.79 & 0.58 & 0.00 & 57.13 & 0.73 & 0.03 & & 1.00 & \\
\hline $\mathrm{Na}_{2} \mathrm{O}$ & 6.67 & 5.90 & 7.49 & 0.94 & 0.00 & 0.00 & 0.00 & 6.86 & -0.19 & & & \\
\hline $\mathrm{K}_{2} \mathrm{O}$ & 5.97 & 4.37 & 6.07 & 0.00 & 0.00 & 0.00 & 0.00 & 5.51 & 0.46 & & & \\
\hline $\mathrm{P}_{2} \mathrm{O}_{5}$ & 0.07 & 0.00 & 0.00 & 0.00 & 0.00 & 0.00 & 42.04 & 0.11 & -0.04 & & & \\
\hline P.I. & 1.08 & 1.96 & & & & & & 99.90 & 0.255 & $=\Sigma r^{2}$ & & \\
\hline
\end{tabular}

(B) Comenditic Trachyte Glass to Pantellerite Melt Inclusion

\begin{tabular}{|c|c|c|c|c|c|c|c|c|c|c|c|c|}
\hline & 150522 & 150514 & Anr & Aug & OI & IIm & $A p$ & & & 150514 & 0.06 & $=\mathrm{F}$ \\
\hline $\mathrm{SiO}_{2}$ & 65.07 & 72.94 & 67.45 & 49.07 & 30.37 & 0.00 & 0.00 & 65.09 & -0.01 & Anr & 0.87 & $92.5 \%$ \\
\hline $\mathrm{TiO}_{2}$ & 0.71 & 0.73 & 0.00 & 0.21 & 0.00 & 52.08 & 0.00 & 0.72 & -0.01 & Aug & 0.02 & $2.6 \%$ \\
\hline $\mathrm{Al}_{2} \mathrm{O}_{3}$ & 16.05 & 5.34 & 18.17 & 0.44 & 0.00 & 0.00 & 0.00 & 16.08 & -0.03 & Ol & 0.03 & $3.2 \%$ \\
\hline $\mathrm{FeO}^{*}$ & 4.30 & 9.99 & 0.76 & 25.20 & 60.08 & 45.73 & 0.57 & 4.29 & 0.01 & $\mathrm{IIm}$ & 0.01 & $1.4 \%$ \\
\hline $\mathrm{MnO}$ & 0.17 & 0.45 & 0.00 & 1.46 & 4.03 & 1.99 & 0.20 & 0.21 & -0.04 & Ap & 0.00 & $0.3 \%$ \\
\hline $\mathrm{MgO}$ & 0.21 & 0.13 & 0.00 & 3.88 & 4.93 & 0.20 & 0.06 & 0.25 & -0.04 & & 1.00 & \\
\hline $\mathrm{CaO}$ & 0.76 & 0.46 & 0.07 & 18.79 & 0.58 & 0.00 & 57.13 & 0.73 & 0.04 & & & \\
\hline $\mathrm{Na}_{2} \mathrm{O}$ & 6.67 & 5.63 & 7.49 & 0.94 & 0.00 & 0.00 & 0.00 & 6.86 & -0.19 & & & \\
\hline $\mathrm{K}_{2} \mathrm{O}$ & 5.97 & 4.32 & 6.07 & 0.00 & 0.00 & 0.00 & 0.00 & 5.53 & 0.44 & & & \\
\hline $\mathrm{P}_{2} \mathrm{O}_{5}$ & 0.07 & 0.00 & 0.00 & 0.00 & 0.00 & 0.00 & 42.04 & 0.12 & -0.05 & & & \\
\hline P.I. & 1.08 & 2.61 & & & & & Sum: & 99.88 & 0.240 & $=\Sigma r^{2}$ & & \\
\hline
\end{tabular}

(C) Pantellerite Glass to Pantellerite Glass (Horizontal Trend)

\begin{tabular}{|c|c|c|c|c|c|c|c|c|c|c|c|}
\hline & 150514 & 150544 & Anr & Cpx & Aen & Qtz & & & & & \\
\hline $\mathrm{SiO}_{2}$ & 71.38 & 71.90 & 67.25 & 49.66 & 40.35 & 100.00 & 71.38 & 0.00 & 150544 & 0.92 & $=\mathrm{F}$ \\
\hline $\mathrm{TiO}_{2}$ & 0.36 & 0.50 & 0.00 & 0.39 & 8.83 & 0.00 & 0.81 & -0.45 & Anr & 0.01 & $6.5 \%$ \\
\hline $\mathrm{Al}_{2} \mathrm{O}_{3}$ & 7.34 & 7.73 & 17.89 & 0.12 & 0.50 & 0.00 & 7.23 & 0.11 & Cpx & 0.01 & $10.9 \%$ \\
\hline $\mathrm{FeO}^{*}$ & 9.49 & 8.15 & 1.09 & 26.32 & 40.56 & 0.00 & 9.35 & 0.15 & Aen & 0.04 & $48.3 \%$ \\
\hline $\mathrm{MnO}$ & 0.82 & 0.31 & 0.00 & 1.50 & 1.39 & 0.00 & 0.36 & 0.47 & Qtz & 0.03 & $34.3 \%$ \\
\hline $\mathrm{MgO}$ & 0.13 & 0.09 & 0.00 & 3.09 & 1.09 & 0.00 & 0.15 & -0.02 & & 1.00 & \\
\hline $\mathrm{CaO}$ & 0.20 & 0.26 & 0.00 & 17.05 & 0.55 & 0.00 & 0.42 & -0.21 & & & \\
\hline $\mathrm{Na}_{2} \mathrm{O}$ & 5.90 & 6.46 & 7.52 & 1.87 & 6.69 & 0.00 & 6.27 & -0.37 & & & \\
\hline $\mathrm{K}_{2} \mathrm{O}$ & 4.37 & 4.59 & 6.26 & 0.00 & 0.02 & 0.00 & 4.26 & 0.11 & & & \\
\hline $\mathrm{P}_{2} \mathrm{O}_{5}$ & 0.00 & 0.00 & 0.00 & 0.00 & 0.00 & 0.00 & 0.00 & 0.00 & & & \\
\hline P.I. & 1.96 & 2.02 & & & & & 100.23 & 0.654 & $=\Sigma r^{2}$ & & \\
\hline
\end{tabular}
Minerals: Anr, Anorthoclase; Cpx, clinopyroxene; OI, olivine; IIm, ilmenite; Ap, apatite; Aen, aenigmatite; Qtz, quartz.

Model results: $\mathrm{F}$, liquid proportion; $\Sigma r^{2}$, sum of the squares of the residuals. Apatite and aenigmatite compositions adapted from White et al. (2009). P.I., Peralkalinity Index $\left(\mathrm{mol} .\left(\mathrm{Na}_{2} \mathrm{O}+\mathrm{K}_{2} \mathrm{O}\right) / \mathrm{Al}_{2} \mathrm{O}_{3}\right)$ 
Table 5. Results of geothermometry and oxygen barometry calculated with QUILF95 (Andersen et al ., 1993)

\begin{tabular}{|c|c|c|c|c|c|c|c|c|c|c|c|c|c|c|c|}
\hline \multirow[b]{2}{*}{ Sample } & & \multicolumn{3}{|c|}{ Ilmenite } & \multicolumn{3}{|l|}{ Spinel } & \multicolumn{2}{|l|}{ Olivine } & \multicolumn{2}{|l|}{ Augite } & \multirow[b]{2}{*}{$\mathrm{aSiO}_{2}(\mathrm{Q})$} & \multirow[b]{2}{*}{$\mathrm{T}\left({ }^{\circ} \mathrm{C}\right)$} & \multirow[b]{2}{*}{$\log f \mathrm{O}_{2}$} & \multirow[b]{2}{*}{$\Delta \mathrm{FMO}$} \\
\hline & & X-Hem & $\mathrm{X}-\mathrm{Gk}$ & X-Py & $\mathrm{N}-\mathrm{Ti}$ & $\mathrm{N}-\mathrm{Mg}$ & $\mathrm{N}-\mathrm{Mn}$ & X-Fo & X-La & X-En & X-Wo & & & & \\
\hline \multirow[t]{2}{*}{160541} & Input & 0.042 & 0.013 & 0.047 & & & & 0.079 & 0.008 & 0.125 & 0.428 & & & & \\
\hline & Calc & & 0.012 & & & & & & 0.008 & & & 0.942 & 793 & -15.7 & -1.01 \\
\hline \multirow{2}{*}{150513} & Input & 0.047 & 0.024 & 0.056 & & & & 0.069 & 0.006 & 0.112 & 0.435 & & & & \\
\hline & Calc & & 0.009 & & & & & & & 0.121 & & 0.976 & 736 & -16.6 & -0.58 \\
\hline \multirow[t]{2}{*}{150522} & Input & + & & & & & & 0.251 & 0.009 & 0.283 & 0.270 & & & & \\
\hline & Calc & & & & & & & & & 0.270 & & 0.743 & 881 & & \\
\hline \multirow[t]{2}{*}{150534} & Input & 0.035 & 0.016 & 0.044 & 0.723 & 0.017 & 0.053 & & & 0.101 & 0.424 & & & & \\
\hline & Calc & & 0.010 & 0.032 & & 0.012 & & & & & & 0.773 & 820 & -15.8 & -1.73 \\
\hline \multirow[t]{2}{*}{150541} & Input & + & & & 0.667 & 0.021 & 0.055 & 0.153 & 0.007 & 0.195 & 0.419 & & & & \\
\hline & Calc & & & & & 0.026 & & & & 0.207 & & 0.904 & 804 & -15.2 & -0.78 \\
\hline \multirow[t]{2}{*}{150551} & Input & 0.013 & 0.008 & 0.042 & & & & 0.126 & 0.011 & 0.138 & 0.423 & & & & \\
\hline & Calc & & 0.021 & & & & & & & 0.170 & & 0.860 & 863 & -15.4 & -2.20 \\
\hline \multirow[t]{2}{*}{231} & Input & & & & 0.719 & 0.042 & 0.057 & 0.262 & 0.009 & 0.296 & 0.410 & & & & \\
\hline & Calc & & & & & 0.058 & & & & 0.275 & & 0.816 & 904 & -13.4 & -0.95 \\
\hline \multirow[t]{2}{*}{226} & Input & & & & 0.763 & 0.039 & 0.056 & 0.140 & 0.010 & 0.203 & 0.405 & & & & \\
\hline & Calc & & & & & 0.029 & & & & 0.181 & & 0.922 & 879 & -14.2 & -1.31 \\
\hline \multirow[t]{2}{*}{060537} & Input & 0.039 & 0.009 & 0.050 & & & & 0.058 & 0.006 & 0.113 & 0.422 & 1.000 & & & \\
\hline & Calc & & 0.008 & & & & & & & 0.103 & 0.427 & & 744 & -16.7 & -0.89 \\
\hline
\end{tabular}

All results are calculated at $\mathrm{P}=100 \mathrm{MPa}$. Entries in italics in the "Input" row signify values that were set as trial values; the values calculated by QUILF95 are in normal font in the "Calc" row. Silica activity is relative to quartz saturation. $\triangle \mathrm{FMQ}=\log f \mathrm{O}_{2}-\mathrm{FMQ}(\mathrm{T})$. Samples 231 and 226 are from mineral analyses reported by Mahood \& Stimac (1990); sample 060537 is from mineral analyses reported by White et al . (2009). +, present but not analyzed. 